تنمية السياحة البيئية فى مصر و إستراتيجية إدراجها على الخريطة السياحية (بالتطبيق على محمية سانت كاترين)

علاء الدين أسامة عبد اللطيف

قسم الاراسات السياحية ــ معهد القاهرة العالى للسياحة والفنادق بالمقطم

ملخص البحث:

يهدف هذا البحث إلى الوقوف على كافة الإمكانات البيئية الطبيعية لمنطقة سانت كاترين، والعمل على إبراز دور ها المهم في تنمية السياحة

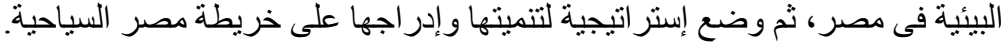

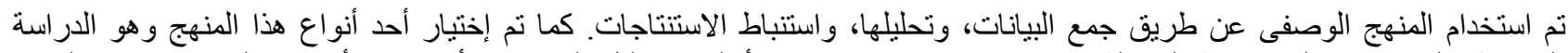

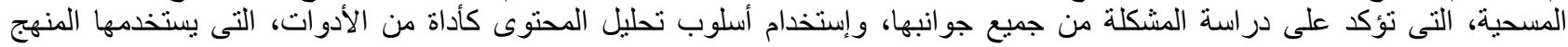
الوصفى، وذللك لتحليل استمار ات الاستبيان، و المقابلات الثخصية.

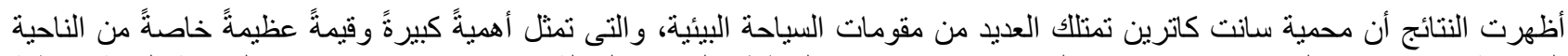

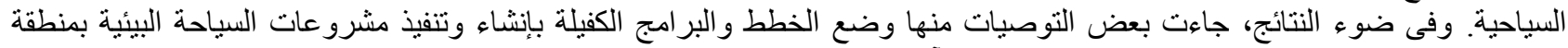

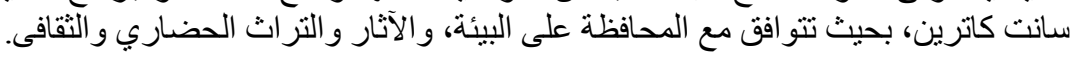
الكلمات الدالة: السياحة البيئية، إستر اتيجية، الخريطة السياحية، محمية سانت كاترين.

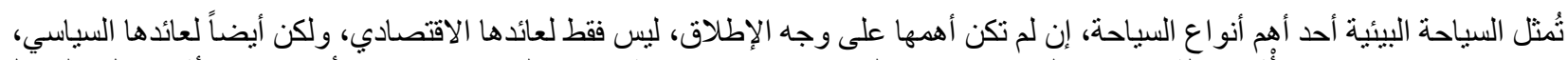

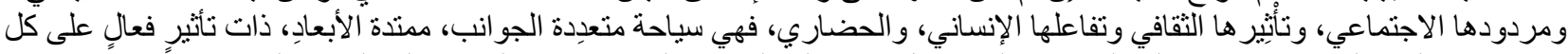

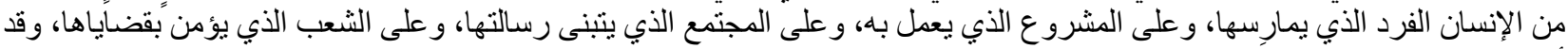

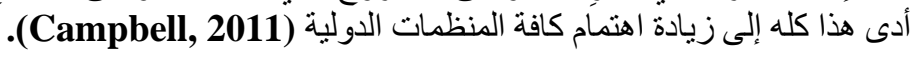

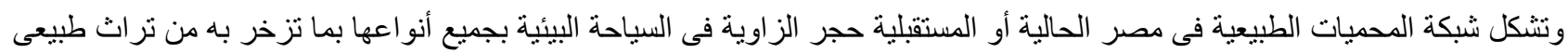

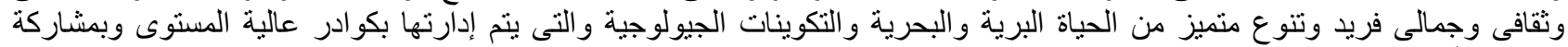

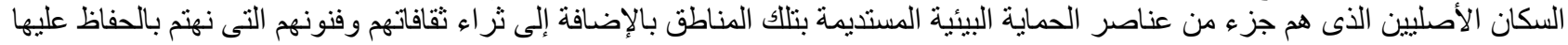

(عبد الرحمن، 2014).

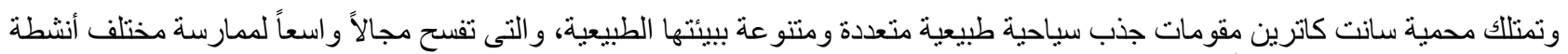

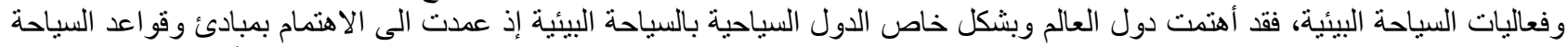
البيئية كمرتكز ات تسترشد بها لتنمية السياحة البيئية من خلال الاستغلال الامثل لمقومات الجذب السياحي البئية الطبيعي (الصيرفى، 2007).

مشكلة البحث:

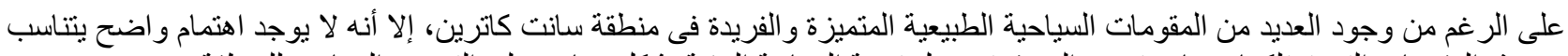

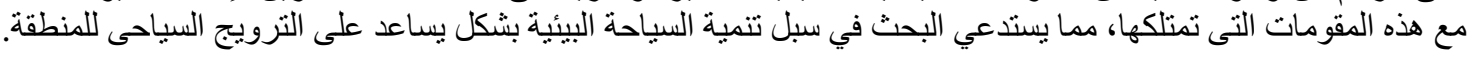

أهداف البحث:

1- التعرف على أهية السياحة البيئية ودور ها المؤثر فى التتمية السياحية.

2- - إلقاء الضوء على أثنكال السياحة البيئية فى مصر.

3- محاولة حصر معوقات تتمية السياحة البيئية.

4- إبراز دور المحميات الطبيعية فى تتمية السياحة البيئية.

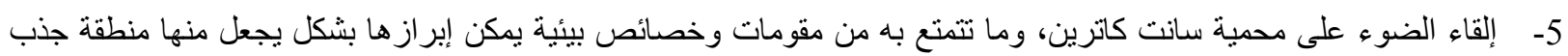

سياحى بيئى.

6- إبر از أثر تتمية السياحة البيئية في منطقة سانت كاترين على المجتمع المحلى.

مفهوم السياحة البيئية:

تعرف السياحة البيئية بأنها مجموعة أفكار وخطوط البئية تهذف جميعها إلى المحافظة على الموروثات السياحية الحضارية والأثرية والدينية و الطبيعية بكل عناصر ها، وفق خطة إستر اتيجية بعيدة المدى تعمل على خلق سياحة شاملة فيلة ورفيقة بالبيئة (Durham, 2008).

كما تعرّف على أنها ظاهرة جغر افية قاعدتها البيئية الطبيعية وبنيانها الاقتصاد ومحركها الإنسان ور ائدها المتعة النفسية و الذهنية (2005,

.(Fennell 
وتعرّف أيضاً بأنها السفر المسئول إلى المناطق الطبيعية الذي يحافظ على البيئة ويدعم تحقيق الرخاء للسكان المحليين ( Butcher,

وقد برز مفهوم السياحة البيئية كاختيار عملى للاستمتاع بالطبيعة والتراث الثقافي المحلي والحفاظ عليهم في آن واحد، وتعتبر السياحة

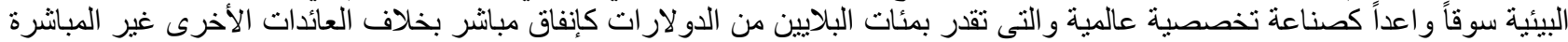

و الوظائف التى توفر ها تلك السوق الضاعة تخمة (عبد اللطيف، 2007).

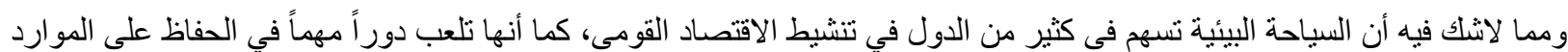

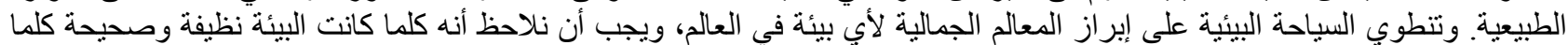

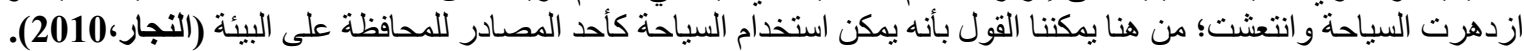

وتعد السياحة البيئية جز عاً من السياحة المستدامة تنبع أسسها من النواحي البيئية و الاقتصادية والاجتماعية، وتسهم بنشاط في المحافظة

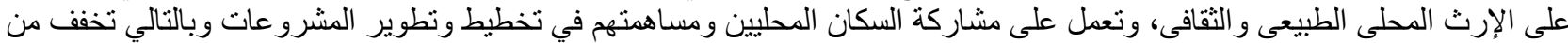

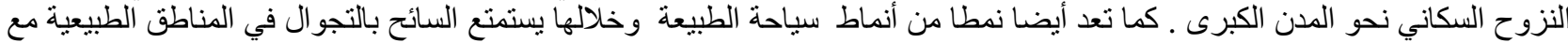

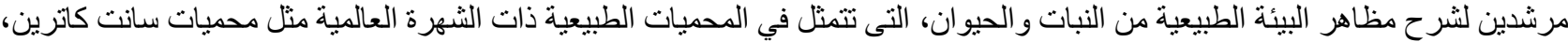

رأس محمد، نبق في جنوب سيناء (عبد الخالق، 2005).

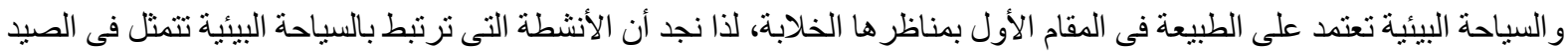

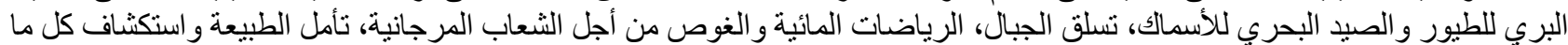

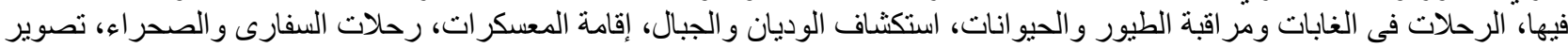

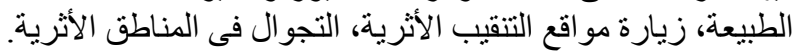

و أهم عنصر تقوم عليه السياحة البيئية هو عدم الإخلال بالتوازن البيئى الناتج عن تصرفات الإنسان والتى تكون منتثلة فى تصرفات

السائح فى حالة السياحة البيئية وما قد يحدثه من تلوث فئه فئه (عبد ربه، 2004).

ومن الملاحظ أن الطلب على هذه النوعية من السياحة فى صعود مستمر وملحوظ، وقد أظهرت نشرة الرؤية السياحية لعام 2020 النية الصادرة عن منظمة السياحة الدولية أن السياحة البيئية أسرع مذه مطاعات سوق السفر نمواً ، و هذا النمو مرتبط بنز ايد الوعي العالمي بالثؤون

البيئية (W.T.O, 2010).

أهمية السياحة البيئية:

تتمثل تلك الأهمية فيما يلى (Buckley,2003):

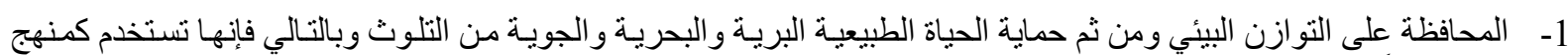

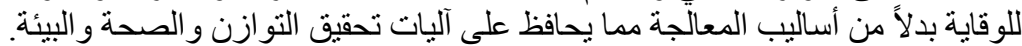

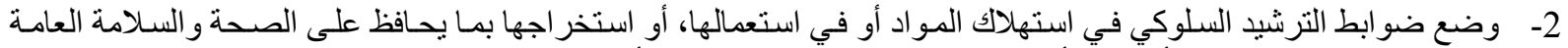

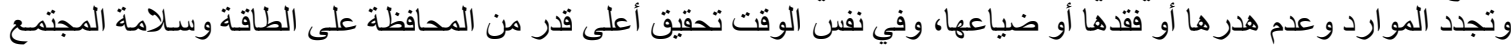

وحيويته وفاعليته.

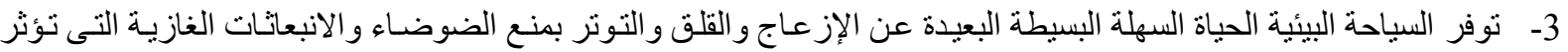

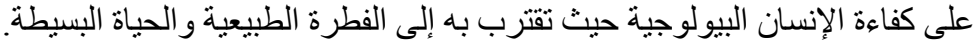

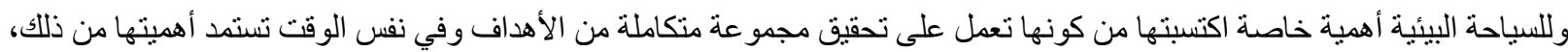

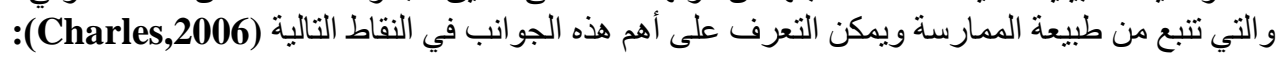

الأهمية الاقتصادية للسياحة البيئية: وتتمثل في المال الاقتصادي الآمن، حيث تعد أماكن ممارسة السياحة البيئية من أكثر الموارد ندرة في

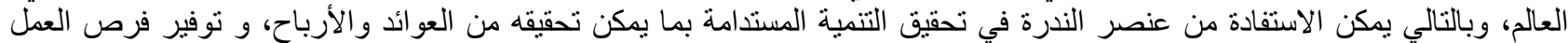

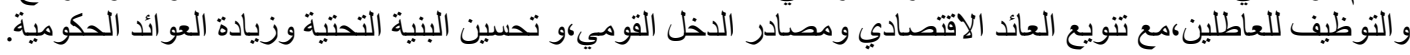
الأهمية السياسية للسياحة البيئية: وتتمثل في الأمن البيئي بعدم تعرض الدول لاضطر ابات بسبب عدم رضا الأفر اد عن التلوث أو الإضرار بالبيئة ويتم تصحيح ذلك بالسياحة لالبياحة البيئية.

الأهمية الاجتماعية للسياحة البيئية: حيث تعد السياحة البيئية صديقة للمجتمع فهى تقوم على الاستفادة مما هو متاح في المجتمع من موارد

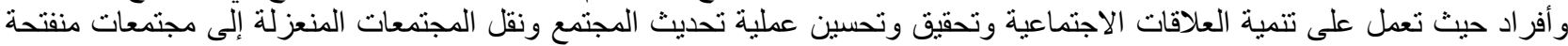

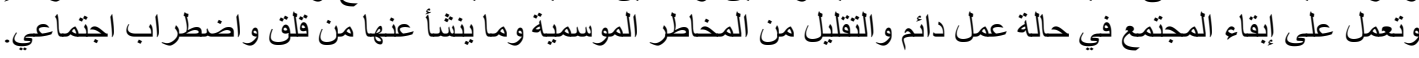
الأهية الثقافية للسياحة البيئية: القائمة على نشر المعرفة وزيادة تأثير المعرفة فى نطوير وتقديم البرامج السياحية البيئية، ونشر ثقافة

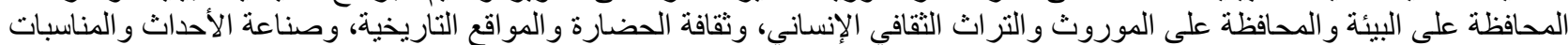

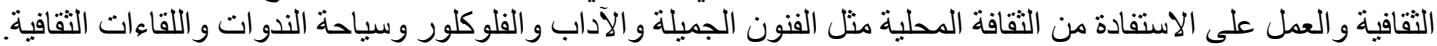


يمكن تحديد أهم خصائص السياحة البيئية في أنها (الصرايرة، 2012):

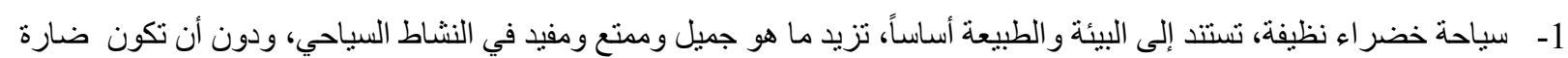
أو مخرّبة أو مفسّدة على المستويات الإيكولوجية ولنية والاجتماعية و الثقافية.

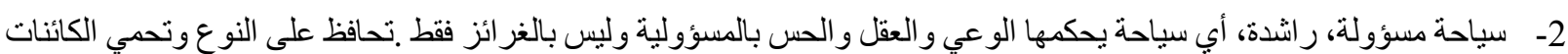

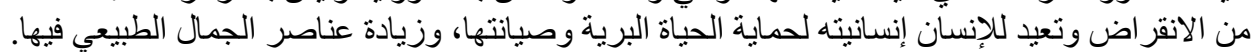

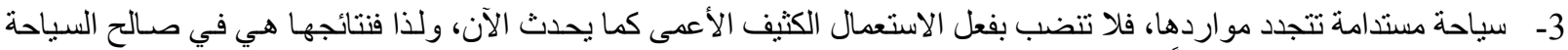

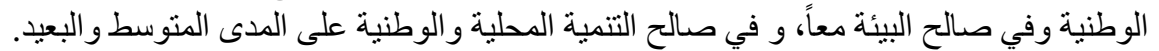

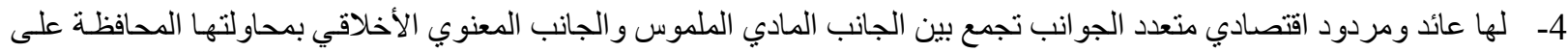

سلامة البيئة.

5- نشاط يجمع بين الأصلالة في الموروث الحضاري الطبيعي و الحداثة في تحضر ها الأخلاقي والقيم، حيث تجمع بين القديم و الحديث، مما يخلق نمطار ائعا في التجانس و التو افق و الاتساق.

مبادئ السياحة البيئية:

لقد وضعت الكثير من دول العالم مبادئ عدة للسياحة البيئية وشروطاً لممارستها، ولعل أهمها مايلى (شحاتة، 2006، اللحام، 2008): 1- توفير مر اكز دخول محددة تزود السائح بالمعلومات اللازمة عن منطقة السياحة من خلال المجتمع المحلي للمنطقة، وإدارة سليمة

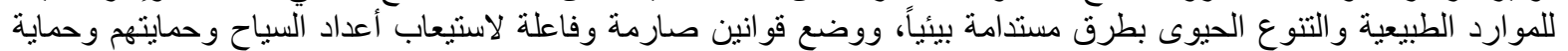

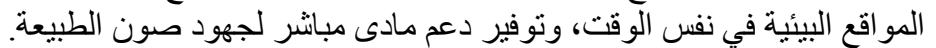

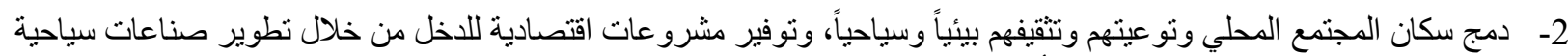

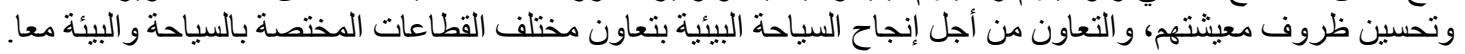

3- تقليص التأثير على البيئة بحساب الزوار بناءاً على الطاقة الاستيعابية للمكان، وبناء قاعدة من الوعى والتقدير لدور البيئة والثقافة

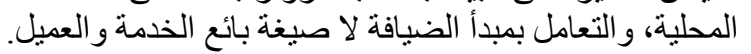

4ـ توفير فرص الاستثمار و العمل لرفع المستوى المعيشى للسكان المحليين. واحترام الإعلان العالمى لحقوق الإنسان واتفاقيات حماية العمال.

5- تعنمد على السفر إلى مناطق طبيعية.

6- تحنوي على نشاطات سياحية تقلل من الاثار السلبية على السكان المحليين .

7- - توفر السياحة البيئية مجموعة من الفوائد للسكان المحليين.

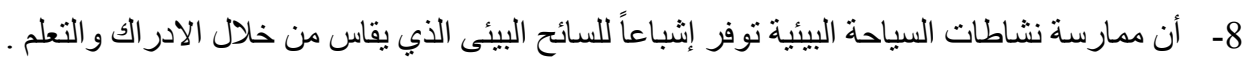

9- تنطوي ممارسة نشاطات السياحة البيئية على جو انب معرفية وجو انب عاطفية لذلك تتطلب مستوى عالياً من الدقة في الاعداد.

معوقات السياحة البيئية فى مصر:

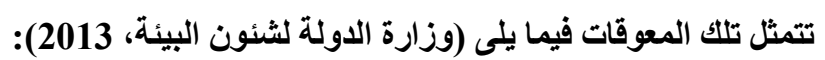

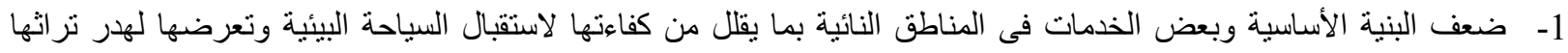

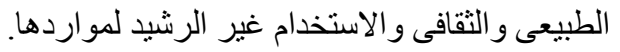

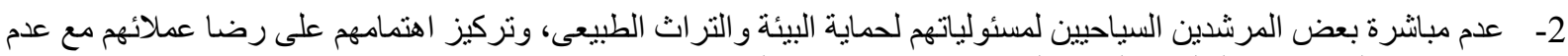
إثنائهم عن الممارسات السلبية و السماح لهم بجمع تذكار ات من الطبيعية.

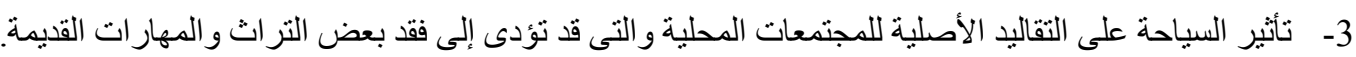

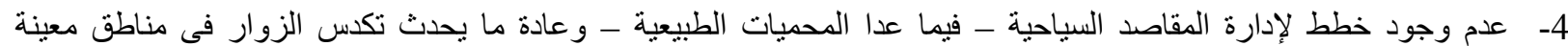

وبأسلوب عشو ائى دون اعتبار للقدرات الاستيعابية للنظم البيئية الهشة وندرة التتوع البيولوجى بهات البها.

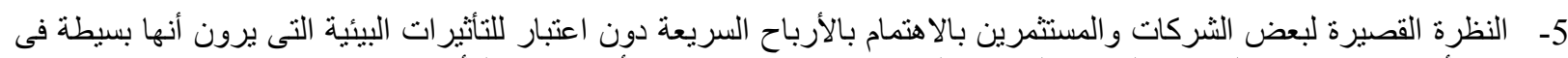
حين أن تر اكمها يؤدى إلى هدر الموارد الطبيعية التى يصعب استعادة كفاءتها أو قد تنتهى للأبد.

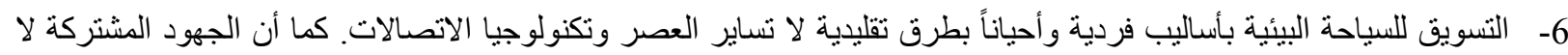

ترتقى إلى نظام عمل الفريق. هذا علاوة على النظرة المحدودة إلى الترويج بالسوق الماير المحلية لهذا النوع من السياحة.

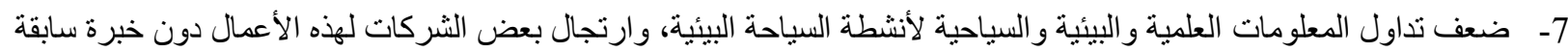

وفى غيية عن تراخيص ومر اقبة أجهزة الدولة. 
8- عدم وجود هيكل مؤسسى قوى بالمجتمع المدنى لرعاية وتنظيم وتكامل أنثطة السياحة البيئية - فيما عدا تنظيمات لأنشطة متفرقة،

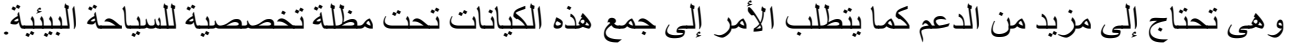

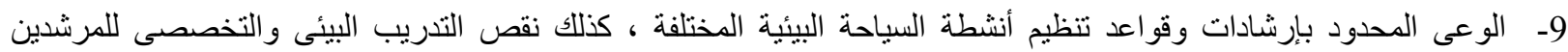

السياحيين و العاملين فى مجال السياحة البيئية.

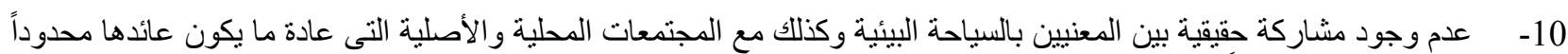

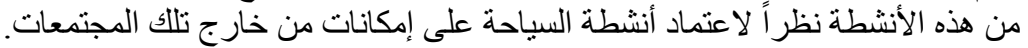

دور السياحة البيئية في التنمية المستدامة:

تمثل السياحة البيئية أحد أنواع السياحة القائمة على مبدأ الاستدامة السياحية وهي تعتمد بشكل رئيسي على على عناصر الطبيعة ثم بليها

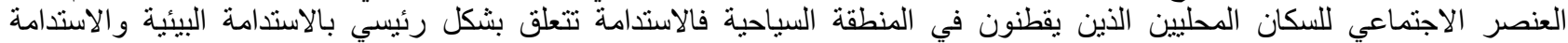

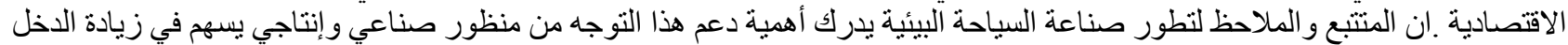

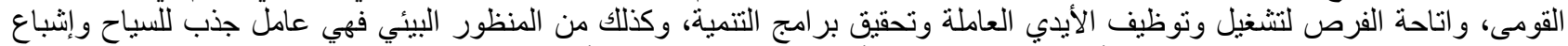

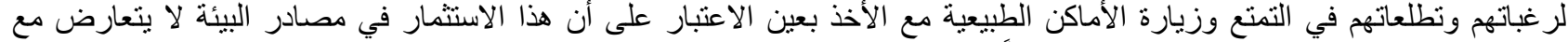
استنز اف ونفاذ هذه الموارد الطبيعية بل يكون مجالاً للمحافظة و الحماية " للسياحة البيئية المستدامة " (عبد الجليل، 2014).

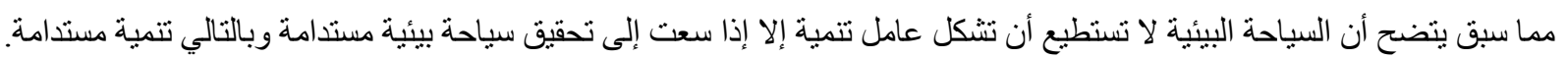

\section{المحميات الطبيعية قاعدة للسياحة البيئية:}

تمثل المحميات الطبيعية مر اكز هامة لجذب السياحة البيئية الدولية والمحلية نظراً لحفاظها على البيئة الطبيعية الفطرية بتلك المناطق التى لئى ينثدها العديد من السياح و التى لم يغير ها فعل البشر.

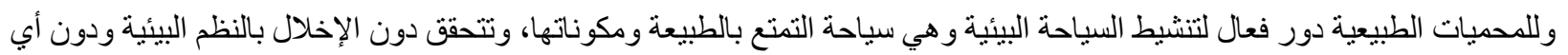
تأثير سلبي على مكونات التتوع الحيوي.

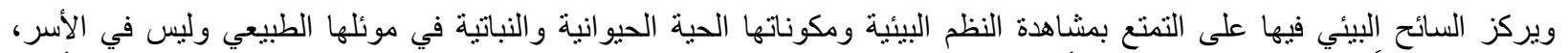

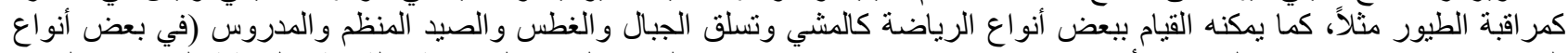

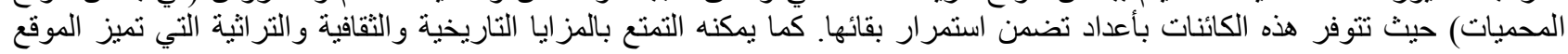

(Alejandro, 2008)

أهداف المحميات الطبيعية:

وتتمثل تلك الأهداف فيمايلى (Paul (2002):

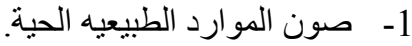

2- الحفاظ على صحة العمليات البيئيه فى النظام البيئى.

3- المحافظه على التنوع الور اثى فى مجمو عات الكائنات الحية النى تتفاعل فى إطار النظام البيئى والمحافظه على قدرنها على أداء أدوار ها.

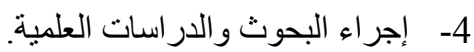

5- 20 - القيام بالأرصاد البيئية.

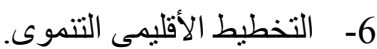

7- المشاركه الثعبية و التعليم و التدريب و الإعلام البيئى.

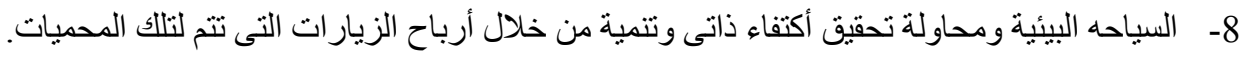

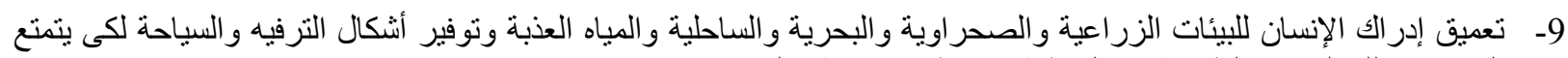

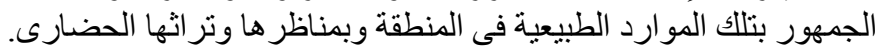

المحميات الطبيعية في مصر:

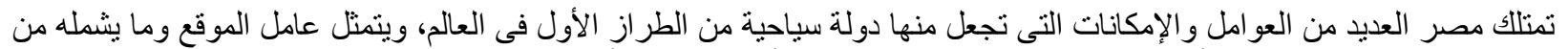

موقع فلكى وجغر افى نسبى، وكذلك أثكال السطح وما يشمله من مظاهر و أنثكال طبيعية أهم عو امل الجذب السيات السيحى فى المحميات الطبيعية.

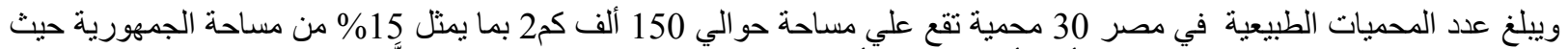

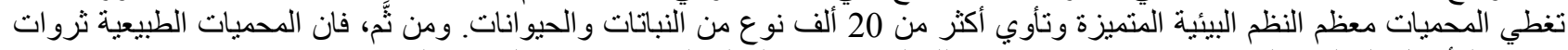
رئيسية للأجيال الحالية والقادمة واحتياطي استراتيجي للاولة، وتسعي الدولة الي حماية هذه الموارد الطبيعية، ورفع كفاءتها كقاعدة وطيدة 
تنمية السياحة البيئية فى مصر و إستراتيجية إدراجها على الخريطة السياحية (بالتطبيق على محمية سانت كاترين)

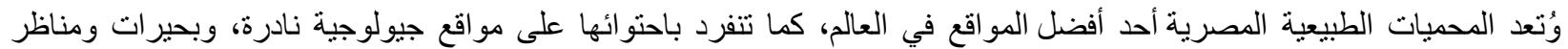

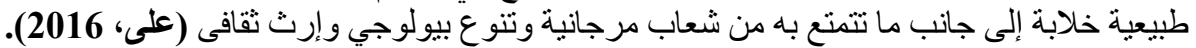

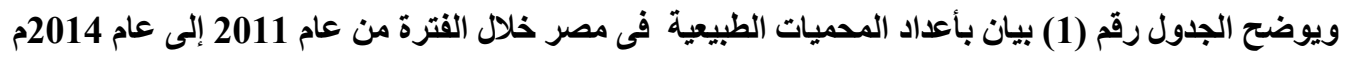

\begin{tabular}{|c|c|c|c|c|c|c|c|c|}
\hline ألزداد & كم2 & الطبيعية & الزداد & كم2 & الطبيعية & أزداد & كم2 & الطبيعية \\
\hline 89053 & 1385 & قارون & 144 & 1 & الدبابية & 424017 & 580 & رأس محمد \\
\hline 38404 & 60 & وادى دجلة & 850 & 35 & الأسيوطى وادى & 18346 & 600 & نبق \\
\hline 451 & 7 & المتحجرة & 122 & 22500 & العلاقىى & 20000 & 500 & أبوجالوم \\
\hline 198 & 1 & قبة الحسنة & 1434 & 0.5 & سالوجا & 48000 & 2595 & طابا \\
\hline 490 & 48523 & الكبير & 120 & 460 & البرلس & 197319 & 4250 & كاترين \\
\hline 22358 & 3010 & البيضاء & 28 & 700 & العميد & 132 & 230 & الزرانيق \\
\hline 6324 & 109 & البحرية & صفر & 383 & السالوم & 64 & 8 & الأحراش \\
\hline 4309 & 7800 & سيوة & 183 & 180 & الجميل & 70000 & 7450 & الجمال \\
\hline صفر & 2 & نيزق & صفر & 12 & سنوف & 246279 & 1991 & جزر الأحمر \\
\hline صفر & 160 & جزر نهر & 89053 & 1759 & والريان & صفر & 35600 & علبة \\
\hline \multicolumn{2}{|c|}{1277678} & & & & & & \multicolumn{2}{|c|}{ المجموع } \\
\hline
\end{tabular}

المصدر: تقرير غير منشور (وزارة الاولة لثشئون البيئة، 2015)

دور المحميات الطبيعية في تنمية السياحة البيئية في مصر:

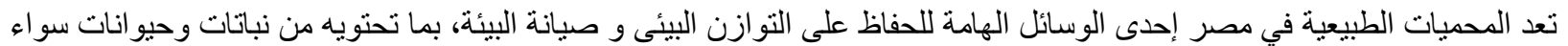
على اليابسة أو فى البحار، ومنع إستنز اف و تدهور الموارد الطبيعية بما يضمن بقاء و حفظ التنوع البيولوجى البئي اللازم لإستمر ار الحياة.

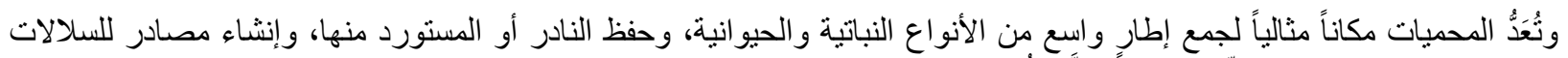

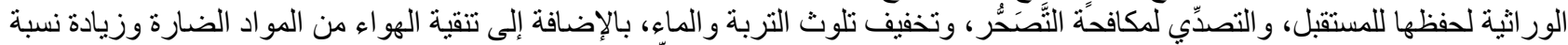

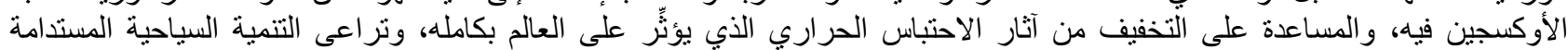

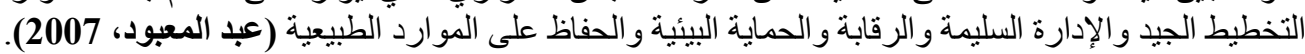

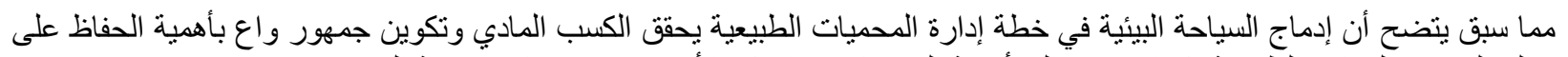

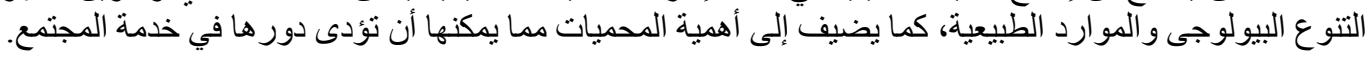


معوقات تنمية المحميات الطبيعية فى مصر:

وتتمنل تللك المعوقات فيما يلى (زين الدين، 2016):

1- ضعف القدرات الفنية والبشرية وقو اعد معلومات التتوع الأحيائي بالمحميات الطبيعية.

2- غياب أو ضعف التشريعات المطبقة على إنشاء المحمية الطبيعية.

3- غياب التخطيط القومى للحفاظ على التتوع الأحيائي .

4- نقص الدر اسات و البحوث المرتبطة بتطوير سبل إدارة المحميات الطبيعية .

5- تعدد الأدارات و المؤسسات المسؤولة عن المحميات الطبيعية والتتوع الأحيائي .

6- قلة الكو ادر و عدم توفر فرص للتدريب.

7- ضعف التمويل المخصص للحفاظ على التنوع الأحيائى الذى بساهم فى توازن البيئة.

دعم العياحة البيئية للمحميات الطبيعية:

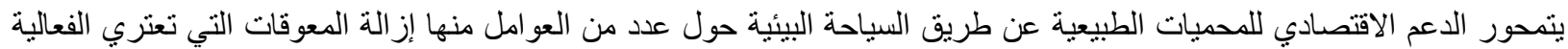

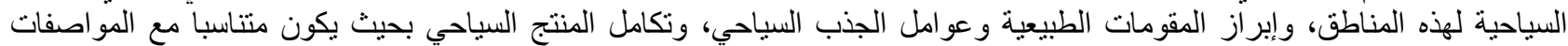

المطلوبة، بجانب تناسب أسعار المر افق السياحية ومنافستها للمر افق الأخرى داخليًا وخارجيًا.

وتحقيق هذا الهذف يتطلب مراعاة المفاهيم السياحية البيئية المنطورة، وأن يتتاسب الهدف مع الموارد والإمكانيات السياحية المتاحة،

وتوفر الخبرات السياحية المتخصصة.

إن المحميات الطبيعية من أهم مر افق السياحة البيئية ويجب دعمها للارتقاء بالو اقع البيئي فيها، و التي بدورها سوف تحقق دعما اقتصاديا

كبير التلك المناطق (القصاص، 2007).

تنمية المحميات الطبيعية فى مصر كأحد مقومات السياحة البيئية:

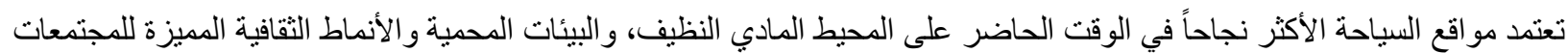

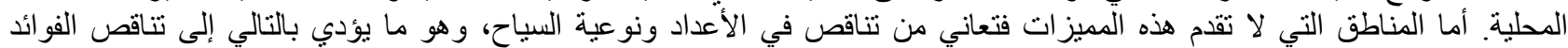

الاقتصادية للمجتمعات المحلية.

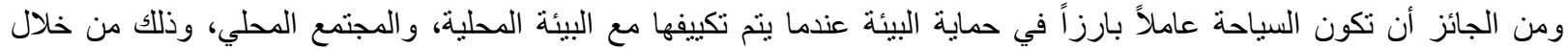

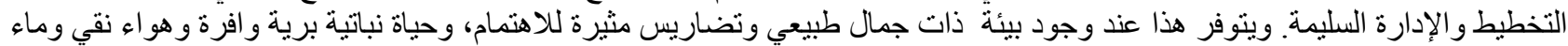

نظيف، مما يساعد على إجتذاب السياح (فودة، 2009).

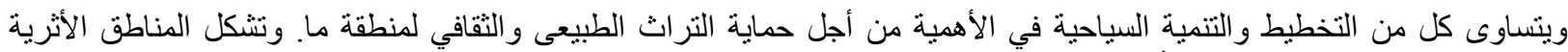

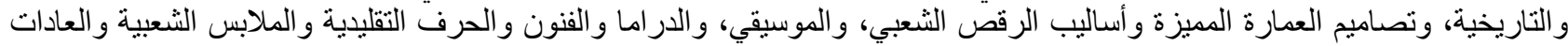

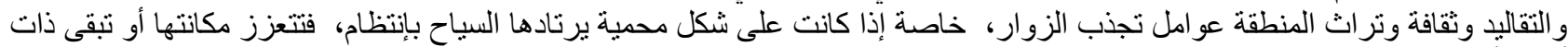

أهمية أُقل، وكل ذلك يرجع للطريقة التي يتم بها تنمية السياحة وإدارتها (وه الندان، 2013).

محمية ساتت كاترين نموذج للسياحة البيئية فى مصر:

تقع مدينة سانت كاترين فى قلب محافظة جنوب سيناء على بعد 300 كم من قناة السويس، وتبلغ مساحتها

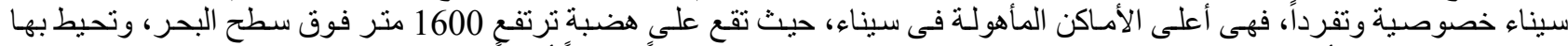

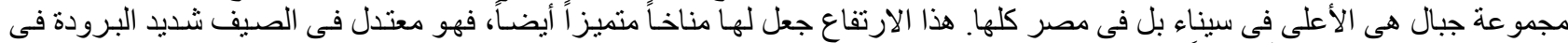

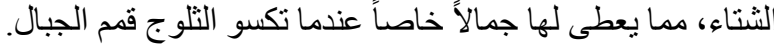

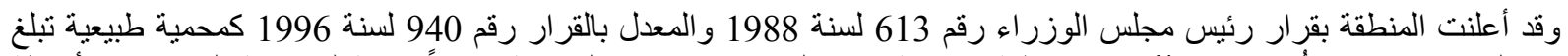

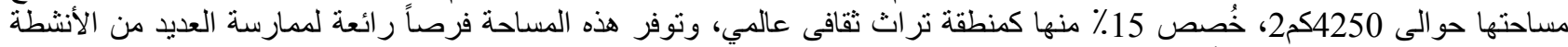

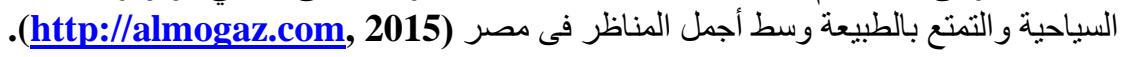

مقومات السياحة البيئية بسانت كاترين: 1 - 1 - 1 محيَّة سانت كاترين:

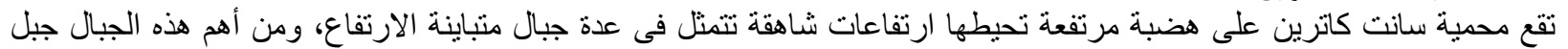

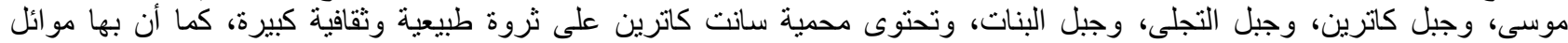

صحر اوية طبيعية للعديد من الأحياء النباتية و الحيو انية (http://www.southsinai.gov.eg, 2017).

ومن أمثلة الثروات الطبيعية الموجودة فى محمية سانت كاترين مايلى (الهيئة العامة للإستعلامات، 2017):

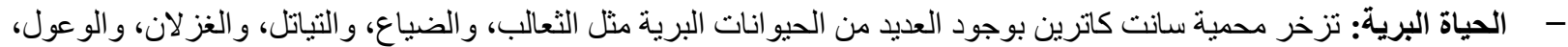

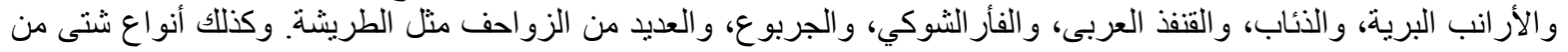




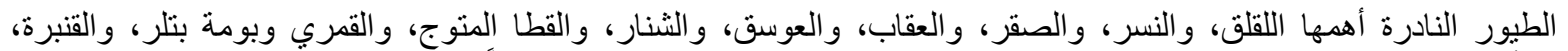

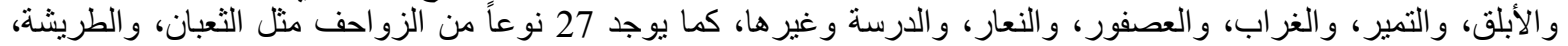
و الضب، و الورل، و الحية و غير ها.

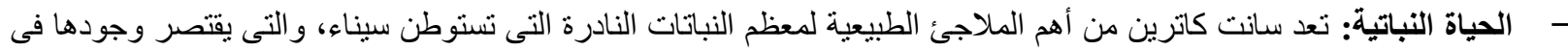

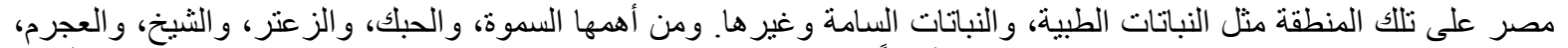

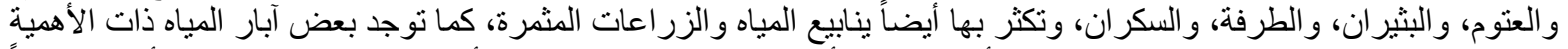

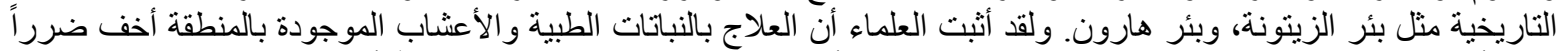

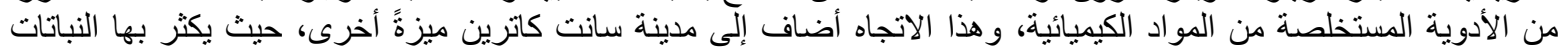

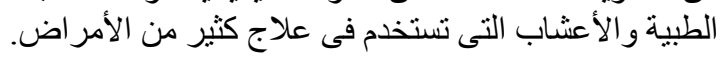

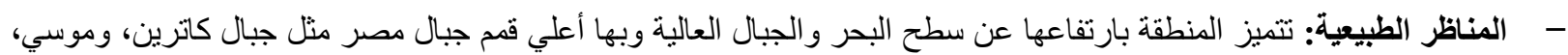

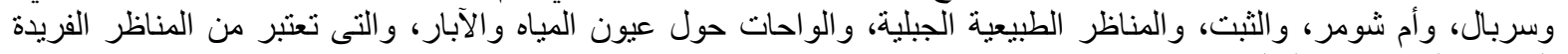

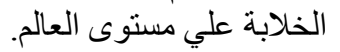

2- 20 - دير سانت كاترين:

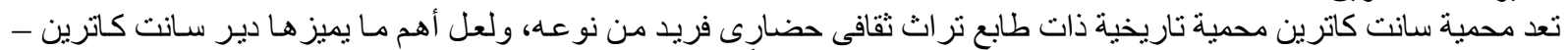

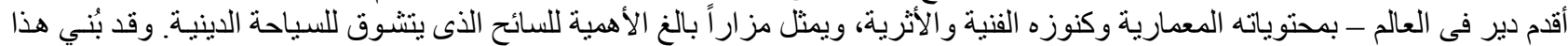
الدير في القرن السادس الميلادى.

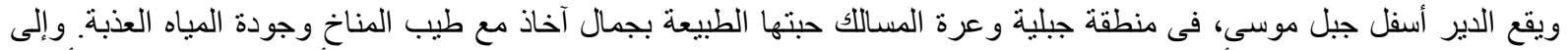

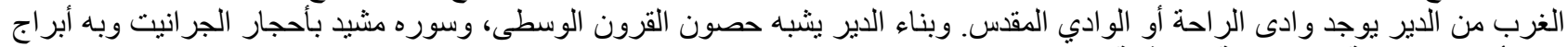

فى الأركان (البو ابة الإكترونية لمحافظة جنوب سيناء، 2017).

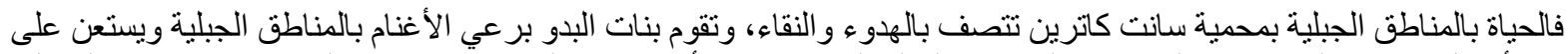

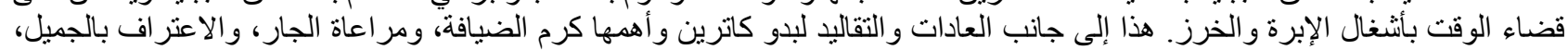

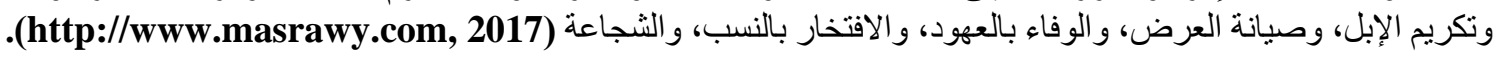

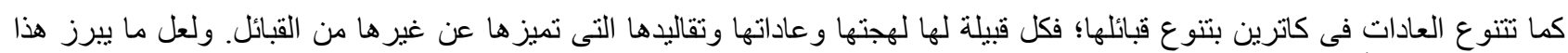

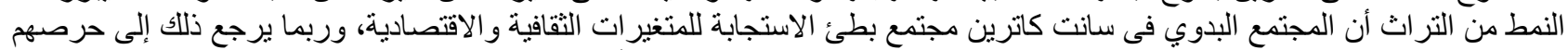

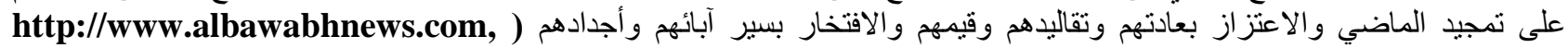

3- 3 - مركز زوار محمية سانت كاترين:

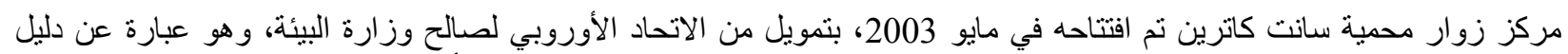

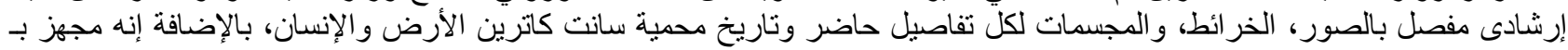
Sound System :(http://www.elfagr.org, 2016) - - ق قاعات المركز وقاعة الاستقبال: يوجد بها ترحيب بـ "38" لغة وتستعرض قوانين المحمية وقصة مركز الزوار.

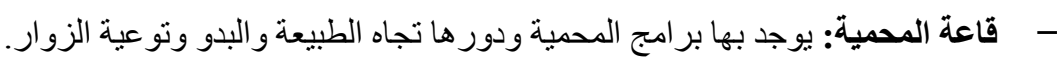

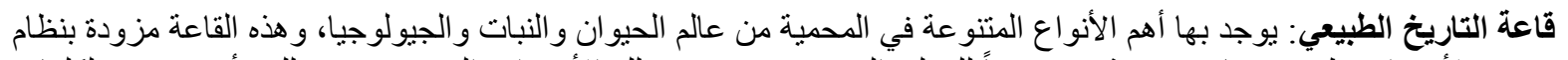

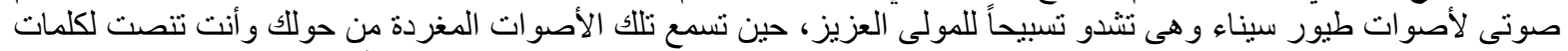

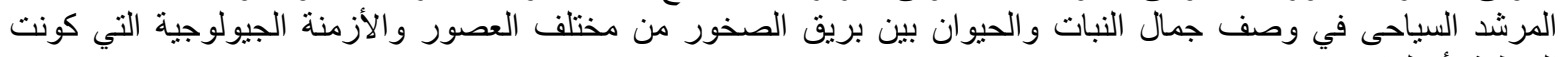
المنطقة بأكملها.

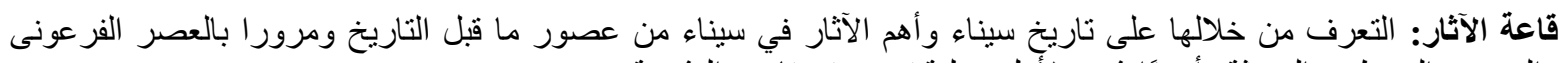

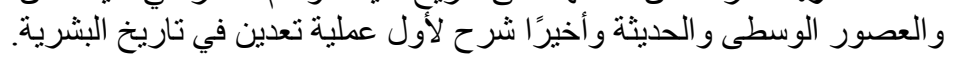

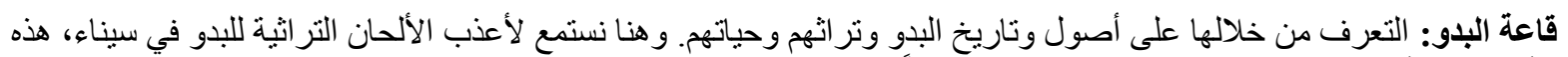

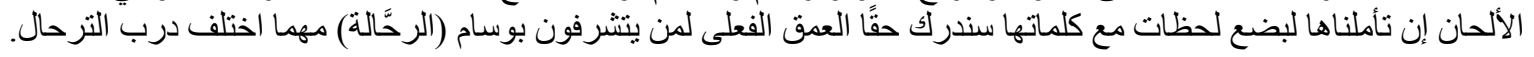
- ماعة الدير: تضم شرحاً و افياً لدير سانت كاترين كما تحتوى القاعة على مجسم للاير. 
4- - الصناعات البيئية داخل مدينة ساتت كاترين: يوجد بمدينة سانت كاترين العديد من مر اكز الحرف و الصناعات اليدوية التى ماز الت تتمنع بروح الأصالة، ويوضح الجدول رقم (2) أهم الصناعات البيئية فى المنطقة:

\begin{tabular}{|c|c|c|c|}
\hline التطريز والأشغال اليلوية & & منتجات النخيل & \\
\hline صناعة الخرز & - & الأقفاص - الحصبر - المقاطف & - \\
\hline المناديل و الطرح & - & السلال و الأطباق من النخيل & - \\
\hline صناعة الطو اقى & - & البر انيط ـ الليف & - \\
\hline وبر الجمال ومنتجاته & - & تجفيف البلح & - \\
\hline الأحزمة و العباءات و الثالات & - & & \\
\hline
\end{tabular}

المصدر : (محافظة جنوب سيناء، مركز المعلومات ودعم اتخاذ القرار،إدارة الإحصاء،2015)

أثر تنمية السياحة البيئية في منطقة ساتت كاترين على المجتمع المحلي: إن الهدف الرئيسى من تتمية السياحة البيئية فى منطقة سانت

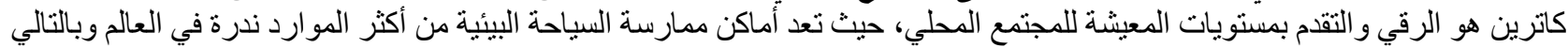

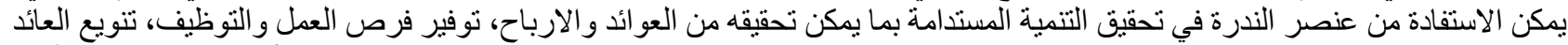

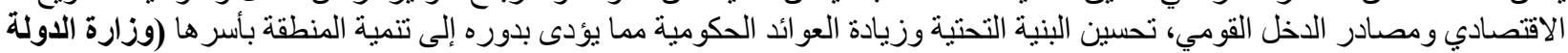

لشئون البيئة، 2015).

إستراتيجية تنمية السياحة البيئية بسانت كاترين

تستتد هذه الإستر اتيجية إلى عدة محاور رئيسية لتنمية السياحة البيئية بسانت كاترين لادر اجها على الخريطة السياحية لمصر بصورة فاعلة لعل من أهمها ما يلى الإنتر:

1- تحديد مقومات المقصد السياحى: لتحديد مقومات المقصد السياحى الملائم للنمط السياحى المستهدف يجب تحليل البيئة الداخلية

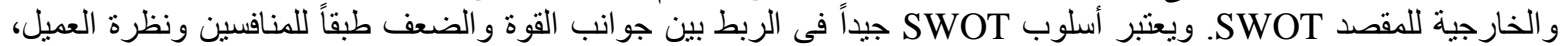

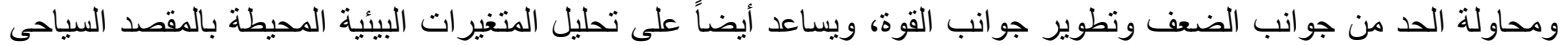

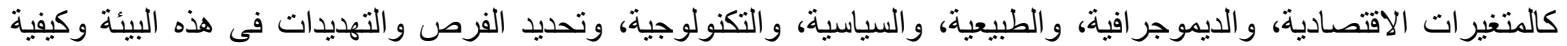
التكيف معها للاستفادة من الفرص المتاحة وتجنب المخاطر و التهديدات (عبد السميع، 2008). ويوضح الجدول رقم (3) أمثلة لنقاط القوة والضعف، والفرص والتهايدات للمقصد السياحى المستهدف:

\begin{tabular}{|c|c|}
\hline Weaknesses & Strengths \\
\hline 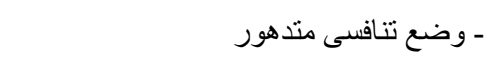 & 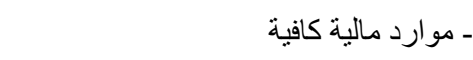 \\
\hline ـ ـ افتقار إلى الموارد البشرية المدربة & ـ مهار ات تتافسية عالية \\
\hline ـ عدم القدرة على مو اجهة الضغوط التنافسية & ـ مكانة معروفة فى السوق \\
\hline ـ ضعف القدرة على التطوير والابتكار & ـ مزيج تسويقى متنوع يلبى رغبات العملاء \\
\hline ـ مهار ات تسويقية ضعيفة لدى رجال البيع & ـ ـ استخدام التكنولوجيا الحديثة \\
\hline ـ عدم مو اكبة التطور ات التكنولوجية & 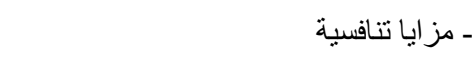 \\
\hline ـ منتجات نمطية و غير متتوعة & ـ القدرة على ابتكار وتطوير منتجات جديدة \\
\hline ـ الانغماس الدائم فى المشكلات الداخلية & 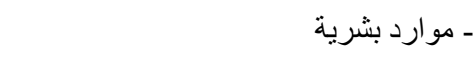 \\
\hline
\end{tabular}


تنمية السياحة البيئية فى مصر و إستراتيجية إدراجها على الخريطة السياحية (بالتطبيق على محمية سانت كاترين)

\begin{tabular}{|c|c|}
\hline Threats & Opportunities \\
\hline - سيو - سئة دخول منافسين جدد & 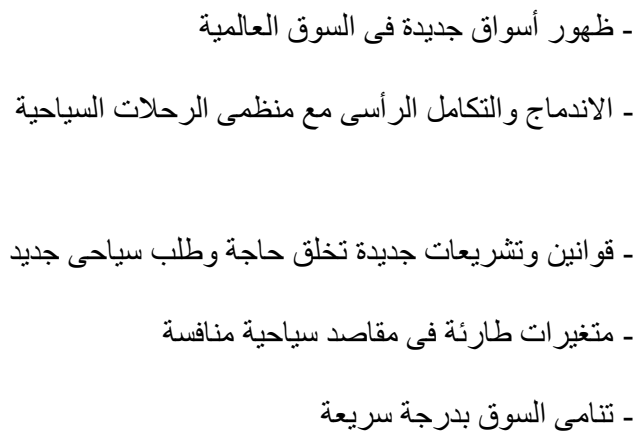 \\
\hline
\end{tabular}

المصدر: (العانى، (لم، (2008)

ومن خلال تحديد وتحليل البيئة الداخلية والخارجية للمقصد السياحى يتم تحديد الثر ائح السوقية، وتوجيه كافة الجهود التسويقية باستغلال ( مصادر القوة الداخلية ) بما يلائم الأهداف (العانى، 2008).

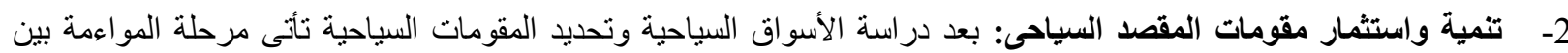

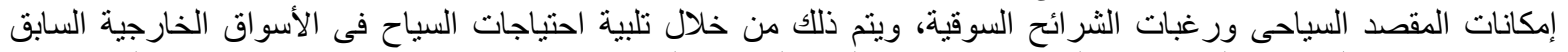

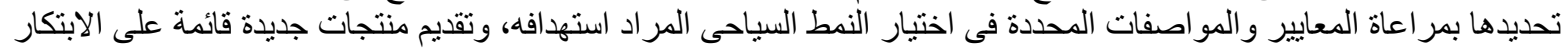

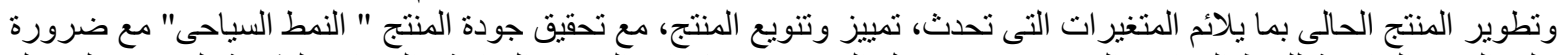

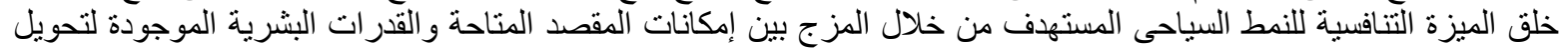

تلألك الإمكانيات الى قيمة متميزة (غانم، 2002).

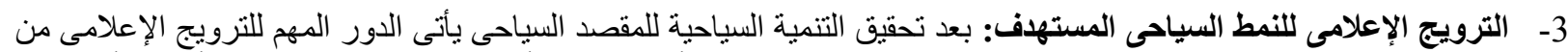

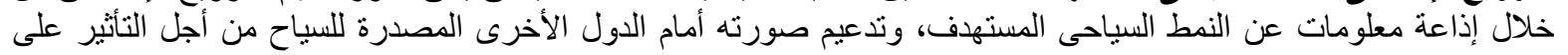

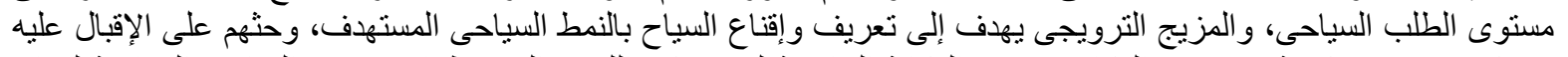

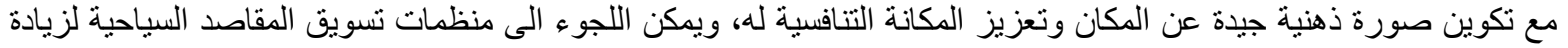
معدلات الزيارة الى منطقة ما وتقع عليها مسئولية تطوير وتحسين صورة المكان المقصود تسويقه وذلك بالتنسيق مع القطاعين العام

و الخاص (حسين، 2009).

4- إدارة منطقة ساتت كاترين سياحياً: هناك العديد من الإجراءات و السياسات التى يمكن إتباعها لتنمية السياحة البيئية بسانت

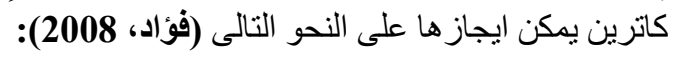

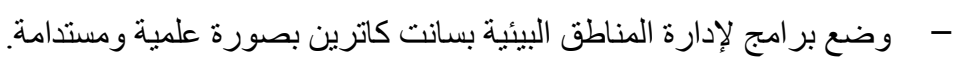

- - تحديد نوعية الزوار المستهدفين وتحديد الطاقة الاستيعابية.

- - تحديد خطة مر اقبة لتأثير السياحة على طبيعة المواقع البيئية بسانت كاترين.

- - در اسة الإمكانية الاقتصادية لنجاح خطة تنتية السياحة البيئية بالمنطقة.

- - در اسة الفو ائد الاقتصادية التى يمكن أن توفر ها الخطة للمناطق البيئية وللسكان المحليين بالمنطقة.

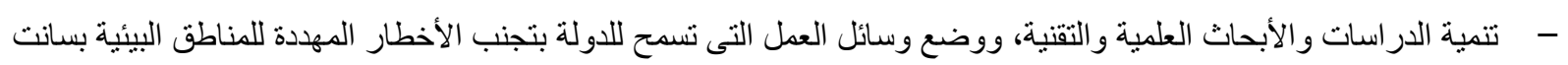
كاترين.

- - ت تمديد أماكن التخييم بالمنطقة.

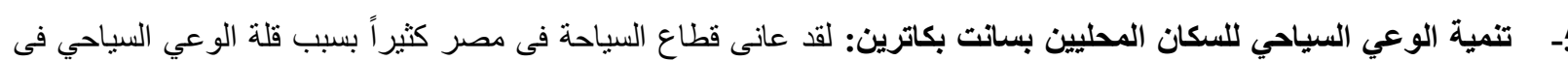

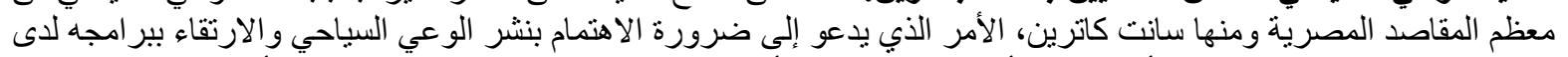

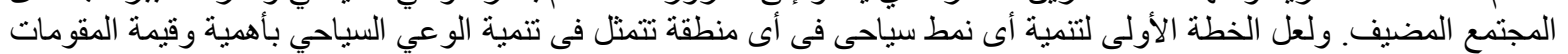

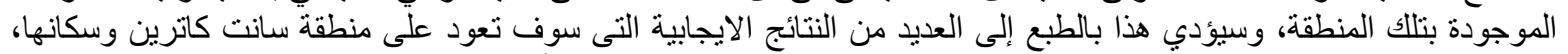

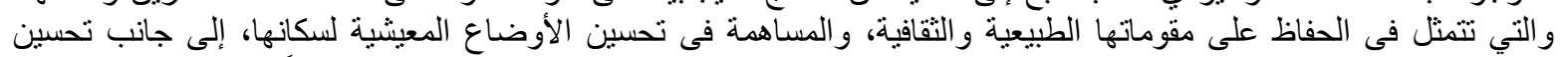

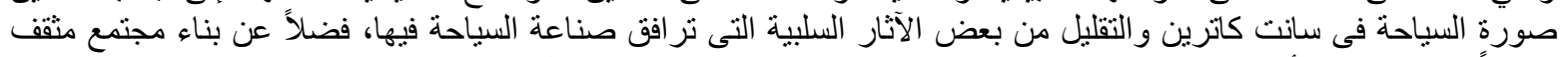

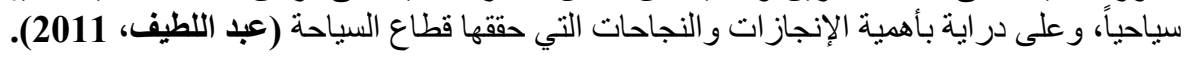

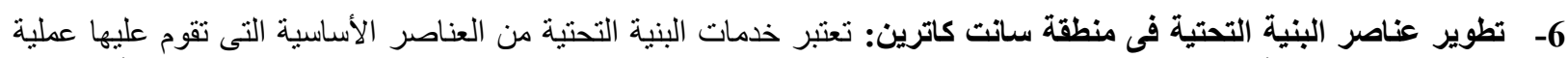

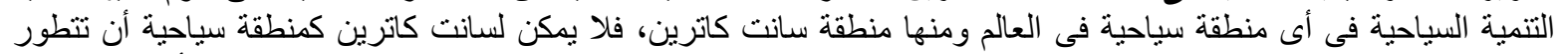
وتزدهر إلا من خلال وجود عناصر البنية التحتية، والعمل على رفع كفاءة خدماتها بثكل عام، ومن ثم تطلب الأمر نوفير هذبه 
العناصر للمناطق البيئية بسانت كاترين، خاصة و أنه لا يمكن تتمية السياحة البيئية بسانت كاترين إلا من خلال تو افر شبكات جيدة

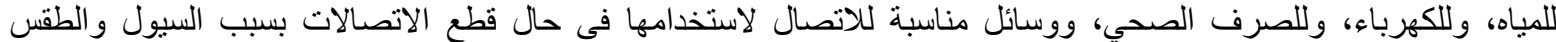

الصعب بسانت كاترين (الخضيرى، 2004).

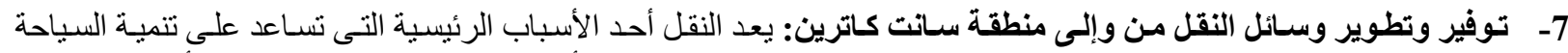

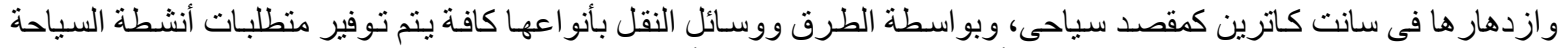

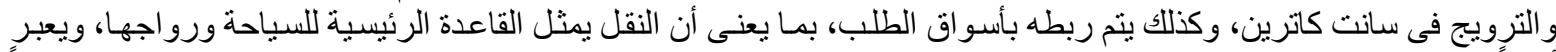

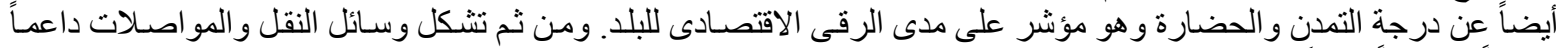

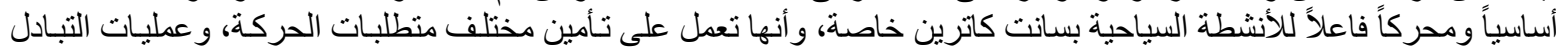

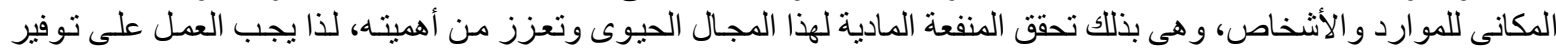

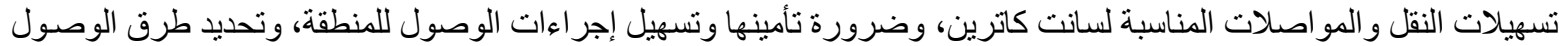

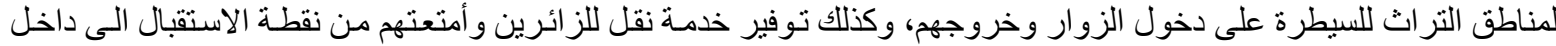

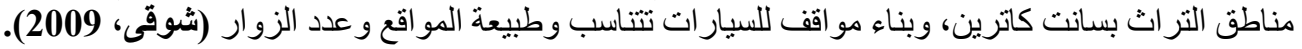

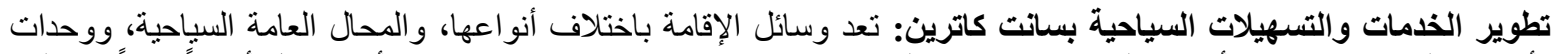

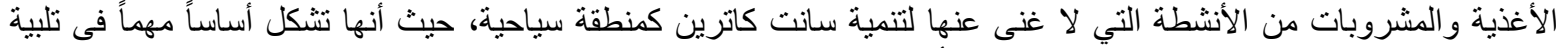

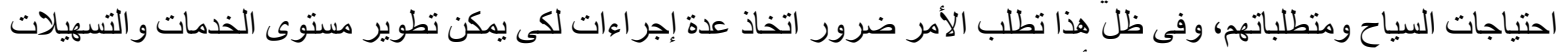
السياحية بمنطقة بسانت كاترين لعل من أهمها: - - توفير وسائل إقامة سياحية بكافة أنو اعها بمستوى من الجودة. - - مضع خطة لتطوير وسائل الإقامة الموجودة فى سانت كاترين بالفعل، وأن تتضمن خطة التطوير دراسة تقييمية لوسائل الإقامة الموجودة لإشباع حاجات الزوار.

- - العمل على توفير وحدات للأغذية و المشروبات بمستوى جودة يتتاسب مع قيمة و أهمية سانت كاترين السياحية (عبد الله، 2013).

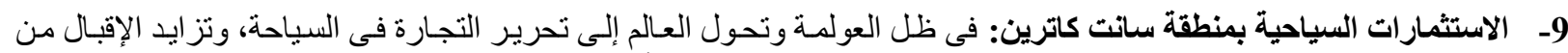

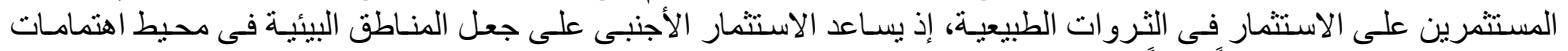

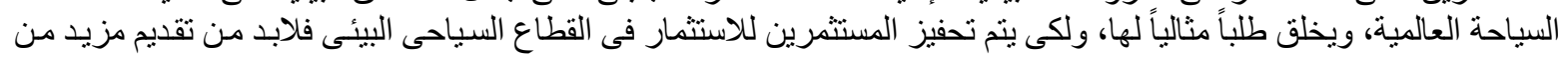

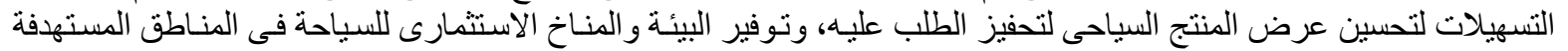

(هلالى، 2011).

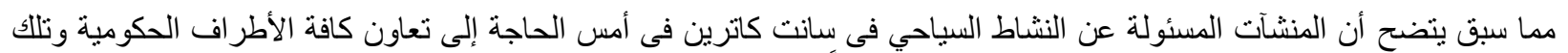

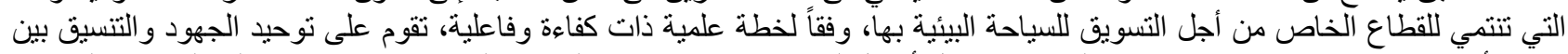

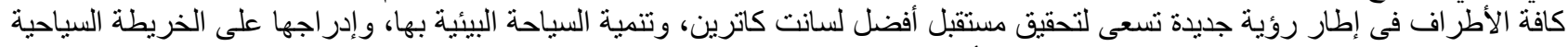
لمصر بصورة تتناسب مع ما تملكه سانت كاترين من أهمية وما لديها من مقومات سياحية.

أولاً: الصورة المبئية للإستبيان :

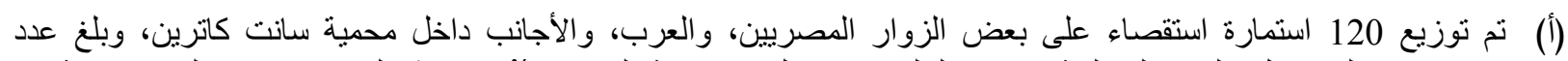

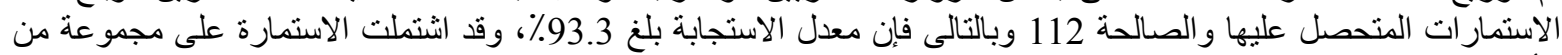

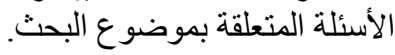

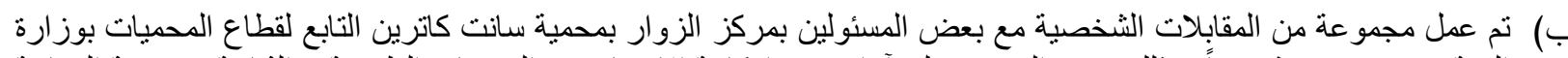

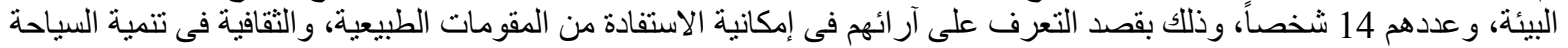

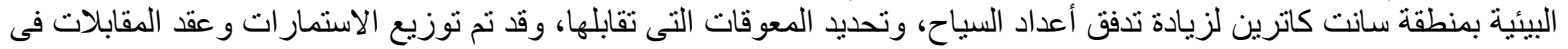

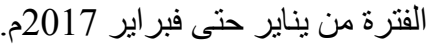

(ج) تم تصميم العبار ات فى القائمة على مقياس ليكرت الثلاثى، ودرجاته (راضى - محايد - غير راضى)، (نعم - لا - إلى حذ ما). 
ثانياً: تحليل استمارة الإستبيان الخاصة بالسياح:

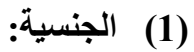

\begin{tabular}{|c|c|c|}
\hline النسبة \% & العدد & الجنسية \\
\hline 35.8 & 40 & مصرى \\
\hline 33.9 & 38 & آسيوى \\
\hline 23.2 & 26 & أوروبى \\
\hline 7.1 & 8 & عربى \\
\hline 100 & 112 & الإجمالى \\
\hline
\end{tabular}

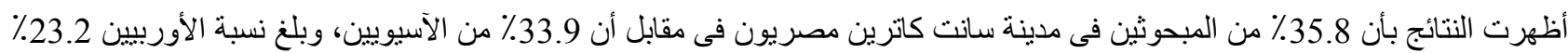
وكان العرب بنسبة 7.1\%، و هذا يدل على ضعن البحف استقطاب السياح العرب للسياحة البيئية.

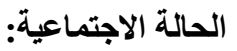

(2)

\begin{tabular}{|c|c|c|}
\hline النسبة \% & العدد العد & الحالة الاجتماعية \\
\hline 33.1 & 37 & أعزب \\
\hline 64.2 & 72 & متزوج \\
\hline 2.7 & 3 & مطلق \\
\hline- & - & أخرى \\
\hline 100 & 112 & الإجمالى \\
\hline
\end{tabular}

يوضح الجدول السابق الحالة الاجتماعية للمبحوثين والتى أظهرت بأن الغالبية العظمى متزوجون بنسبة 64.2٪ يليها الأعزب

بنسبة 33.1 \% و أخيراً المطلق بنسبة 2.7٪.

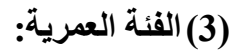

\begin{tabular}{|c|c|c|}
\hline النسبة \% & العدد & العمـر \\
\hline 6 & 7 & $24-18$ \\
\hline 8 & 9 & $34-25$ \\
\hline 25 & 28 & $44-35$ \\
\hline 16 & 18 & $49-45$ \\
\hline 22 & 24 & $54-50$ \\
\hline 17 & 19 & $64-55$ \\
\hline 6 & 7 & أكثر من 65 \\
\hline 100 & 112 & الإجمالى \\
\hline
\end{tabular}


أظهرت النتائج أن الثريحة العمرية الأكثر هى الثريحة من 35 - 45 سنة بنسبة 25٪ يليها الفئة العمرية من سن 50 - 54 - 54 بنسبة 22\% ثم من 55 - 64 بنسبة 17\% ثم 35 - 45 سنة بنسبة 16٪، ويتضح من الجدول السابق أن الثريحة الثبابية تمثل 29٪ و وأن شريحة

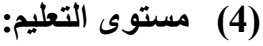

\begin{tabular}{|c|c|c|}
\hline النسبة \% & العدد & المستوى \\
\hline 12 & 13 & در اسات عليا \\
\hline 76 & 86 & تعليم عالى \\
\hline 12 & 13 & تعليم متوسط \\
\hline - & - & أساسى \\
\hline 100 & 112 & الإجمالى \\
\hline
\end{tabular}

يشير الجدول السابق إلى مستوى التعليم بين المبحوثين، حيث احتلت شريحة التعليم العالى النسبة الأكبر بنسبة 76٪ وجاءت شريحتا الدر اسات العليا والتعليم الأساسى فى المرتبة الثانية بنسبة 12\% لكلاً منهما.

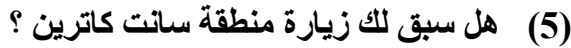

\begin{tabular}{|c|c|c|}
\hline النسبة ٪ & العدد & الإجابة \\
\hline 22.4 & 25 & نعم \\
\hline 77.6 & 87 & ע \\
\hline 100 & 112 & الإجمالى \\
\hline
\end{tabular}

يشير الجدول السابق إلى أن أغلب المبحوثين لم يسبق لهم زيارة منطقة سانت كاترين بنسبة 77.6\%، وبنسبة 22.4\% سبق لهم زيارة المنطقة

(6) - (6) - ماهى أسباب زيارة منطقة سانت كاترين؟

\begin{tabular}{|c|c|c|}
\hline النسبة ٪ & العدد & أسباب الزيارة \\
\hline 46.4 & 52 & علمية \\
\hline 26.7 & 30 & ثقافية \\
\hline 16.2 & 18 & دينية \\
\hline 10.7 & 12 & ترفيهية \\
\hline 100 & 112 & الإجمالى \\
\hline
\end{tabular}

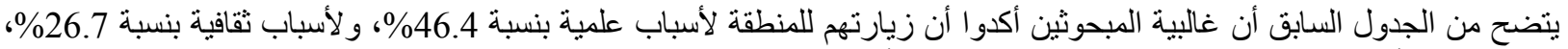
وبنسبة 16.2\% لأسباب دينية، وجاءت في المرتبة الرابعة الأسباب الترفيهية بنسبة 10.7\%؛ و هذا يدل على تمنع المنطقة بتعدد مقومات الجذب السياحى. 
تنمية السياحة البيئية فى مصر و إستراتيجية إدراجها على الخريطة السياحية (بالتطبيق على محمية سانت كاترين)

(7) هل تعتبر ساتت كاترين مقصداً متميزاً للسياحة البيئية؟

\begin{tabular}{|c|c|c|}
\hline النسبة ٪ & العدد & الإجابة \\
\hline 91 & 102 & نعم \\
\hline- & - & ע \\
\hline 9 & 10 & ربما \\
\hline 100 & 112 & الإجمالى \\
\hline
\end{tabular}

أظهرت النتائج بأن غالبية المبحوثين أكدوا على أن منطقة سانت كاترين مقصداً متميزاً للسياحة البيئية بنسبة 91\%، و هذا يدل على تو افر مقومات السياحة البيئية بالمنطقة.

(8) (8) ماهى المناطق السياحية البيئية التى قمت بزيارتها فى ساتت كاترين؟

\begin{tabular}{|c|c|c|}
\hline النسبة \% & 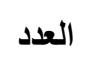 & المنطقة \\
\hline 100 & 112 & جبال سانت كاترين \\
\hline 100 & 112 & دير سانت كاترين \\
\hline 100 & 112 & مناطق الحياه الحيو انية و النباتية \\
\hline 100 & 112 & مركز زوار المحمية \\
\hline
\end{tabular}

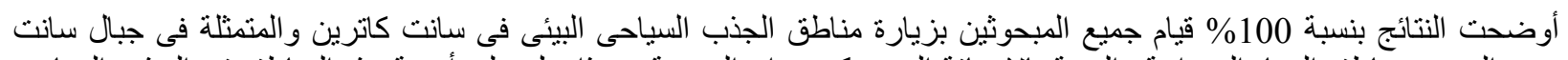

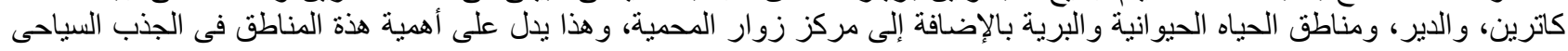

(9) ماهى مصادر معلوماتك لزيارة المناطق السياحية فى سانت كاترين؟

\begin{tabular}{|c|c|c|}
\hline النسبة \% & العدد العد & الوسيلة \\
\hline 8 & 9 & وسائل الإعلام \\
\hline 26 & 29 & شركات السياحة \\
\hline 33 & 37 & الأصدقاء و المعارف \\
\hline 31 & 35 & المو اقع الألكترونية \\
\hline 2 & 2 & أخرى \\
\hline 100 & 112 & الإجمالى \\
\hline
\end{tabular}

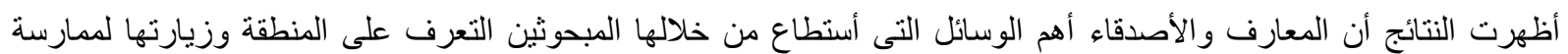

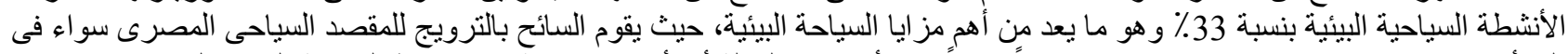

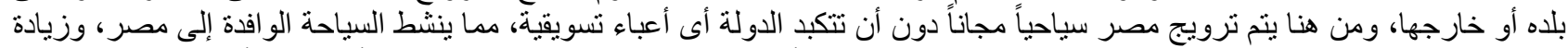

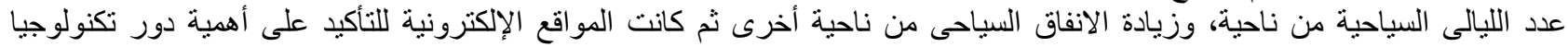

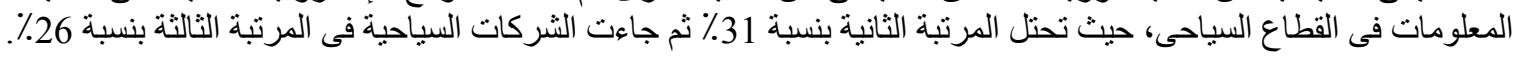


(10) ماهو مستوى الرضا عن الخدمات والتسهيلات المقدمة بالمواقع السياحية فى منطقة سانت كاترين؟

\begin{tabular}{|c|c|c|c|c|c|c|}
\hline \multicolumn{2}{|c|}{ غير راضى } & \multicolumn{2}{|c|}{ محايد } & \multicolumn{2}{|c|}{ 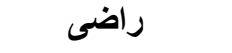 } & \multirow{2}{*}{ الخدمات والتسهيلاتة المتوفرة فى المنطقة } \\
\hline$\%$ & العدد & $\%$ & العدد & $\%$ & العدد & \\
\hline 53.5 & 60 & 10.8 & 12 & 35.7 & 40 & وسائل النقل و المو اصلات \\
\hline 71.4 & 80 & 13.4 & 15 & 15.2 & 17 & خدمات الإقامة اللازمة لبقاء السائح \\
\hline 82.1 & 92 & 6.3 & 7 & 11.6 & 13 & وحالمستوى تقديم للأغذية و المشروبات الجودة \\
\hline 51.8 & 58 & 17.8 & 20 & 30.4 & 34 & مستوى النظافة فى المواقع السياحية \\
\hline 19.6 & 22 & 56.3 & 63 & 24.1 & 27 & 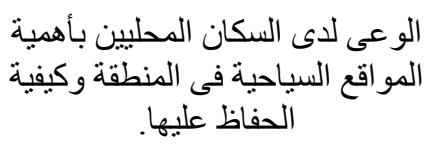 \\
\hline
\end{tabular}

جاء السؤال الثامن من أسئلة استمارة الإستقصاء للتعرف على مستوى الرضا عن الخدمات و التسهيلات المقدمة بالمواقع السياحية فى المنطقة، وقد أنشارت النتائج إلى ما يلى النئ:

• وسائل النقل والمواصلات:

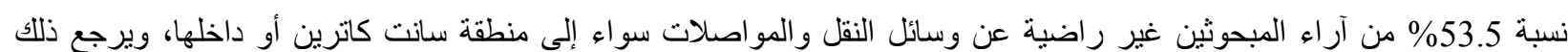

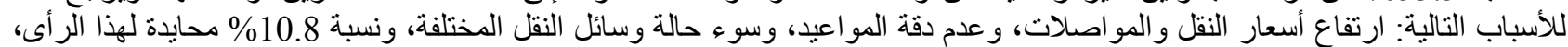
ونسبة 35.7\% من المبحوثين برون عكس ذلك، و هذا يدل على ضعف دور هذا التعا العنصر فى زيادة الحركة السياحية للمنطقة.

\section{• خدمات الإقامة اللازمة لبقاء السائح أطول فترة ممكنة:}

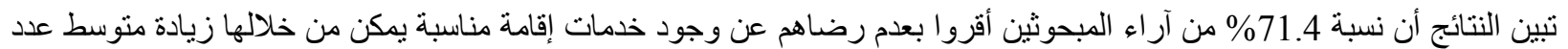

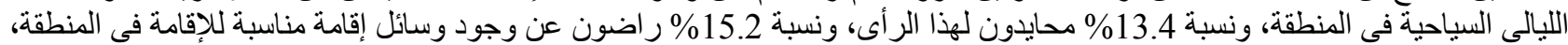
و هذا يدل على ضرورة جذب المزيد من الاستثمار ات السياحية لزيادة عدد أماكن الإقامة وتنو عها.

$$
\text { • وحدات تقديم للأغذية والمشروبات بالمستوى المطلوب من الجودة: }
$$

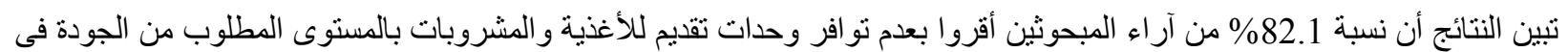

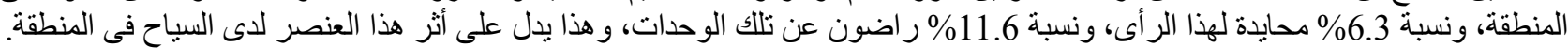

\section{• مستوى النظافة فى المواقع السياحية بالمنطقة:}

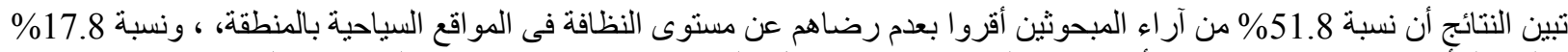

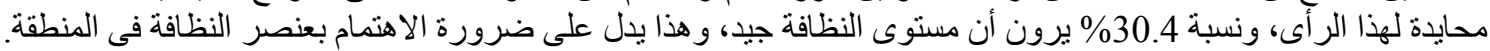

\section{• الوعى لاى السكان المحليين بأهمية المواقع السياحية فى المنطقة وكيفية الحفاظ عليها:}

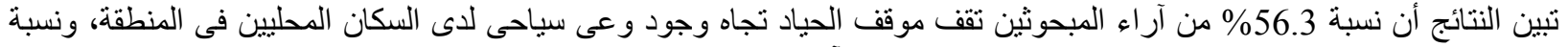

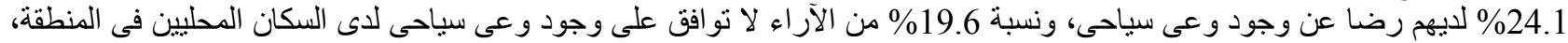
و هذا يدل على ضعف الجهود التو عوية للسكان المحليين بأهمية السياحة فى المنطقة. 
ماهى معوقات جذب السائحين للسياحة البيئية فى منطقة سانت كاترين؟

\begin{tabular}{|c|c|c|c|c|c|c|}
\hline \multicolumn{2}{|c|}{ 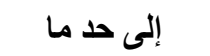 } & \multicolumn{2}{|c|}{ ע } & \multicolumn{2}{|c|}{ نعم } & \multirow[t]{2}{*}{ معوقات جذب السياح فى المنطقة } \\
\hline$\%$ & العدد & $\%$ & العدد & $\%$ & العدد & \\
\hline 10.7 & 12 & 32.1 & 36 & 57.2 & 64 & صعوبة الوصول وسوء حالة \\
\hline 14.4 & 16 & 17.8 & 20 & 67.8 & 76 & ضعف التسهيلات و الخدمات \\
\hline 28.5 & 32 & 37.5 & 42 & 34 & 38 & قلة المياه و عدم صلاحيتها \\
\hline 13.4 & 15 & 15.2 & 17 & 71.4 & 80 & ضعف الخدمات الإرشادية \\
\hline 10.7 & 12 & 7.2 & 8 & 82.1 & 92 & عدم تو افر منشآت الإقامة لأكثر \\
\hline 4.5 & 5 & 53.5 & 60 & 42 & 47 & عدم تو افر المرشدين المحليين \\
\hline 17.8 & 20 & 80.4 & 90 & 1.8 & 2 & عدم توافر عنصر الأمان \\
\hline
\end{tabular}

جاء تحليل آراء المبحوثين حول المعوقات التى تعوق جذب السياح للسياحة البيئية لمنطقة سانت كاترين، كما يلى: • صعوبة الوصول وسوء حالة الطرق و المواصلات:

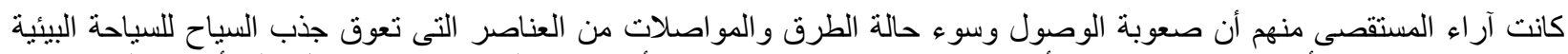

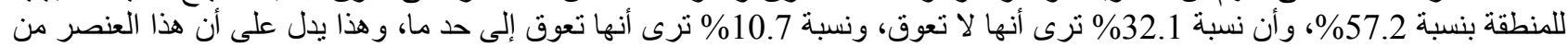
المعوقات التى تو اجه جذب السياح للمنطقة. • م ضعف التسهيلات والخدمات السياحية: بتحليل آراء العينة عن هذا العنصر أنضح أن نسبة 67.8\% من حجم العينة ترى أنه يعوق جذب السياح للسياحة البيئية فى المنطقة، ونسبة 17.8\% ترى أنها لايعوق، ونسبة 14.4 \% نرى أنه يعوق إلى حذ ما، و هذا يدل على نقص العديد من التسهيلات و الخدمات السياحية بالمنطقة.

\section{• ملة المياه و عدم صلاحيتها للشرب:}

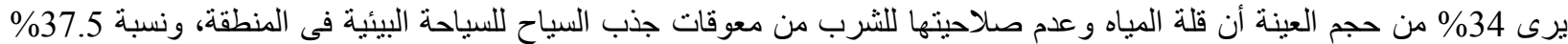
ترى أنها لاتعوق، ونسبة 28.5\% نرى أنها تعوق إلى حد ما، و هذا يدل على أثر هذا العنصر للى العياح السياح فى المنطقة.

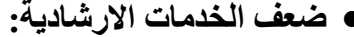

بتحليل آراء العينة عن هذا العنصر أنضح أن نسبة 71.4\% من من حجم العينة ترى أنه يعوق جذب السياح للسياحة البيئية فى المنطقة، ونسبة 15.2 \% ترى أنه لايعوق، ونسبة 13.4\% ترى أنه يعوق إلى حذ ما، و هذا يدل على ضعف الخدمات النه الإرشادية للسياح فى المنطقة.

\section{• عدم توافر منشآت الإقامة لأكثر من يوم:}

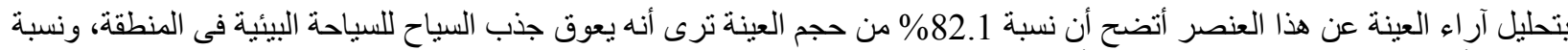

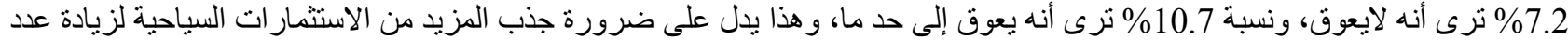
أماكن الإقامة وتنو عها بالمنطقة.

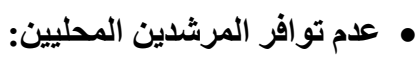

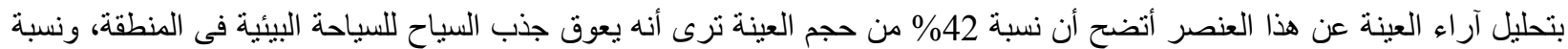

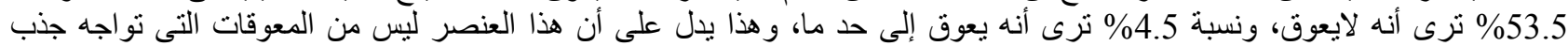




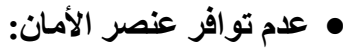

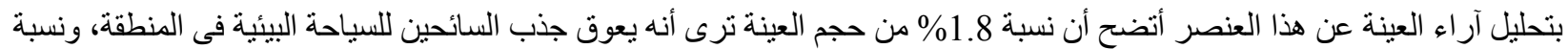

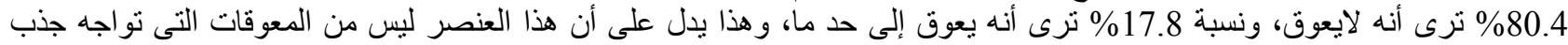

السائحين للسياحة البيئية للمنطقة.

(12) ماهى المقترحات لتنمية السياحة البيئية فى منطقة سانت كاترين؟

\begin{tabular}{|c|c|c|}
\hline 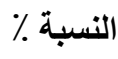 & 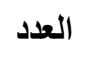 & الإقتراحسات \\
\hline 26.7 & 30 & الاهتمام بإنشاء أماكن الإقامة المختلفة \\
\hline 22.4 & 25 & تحسين عناصر البنية الأساسية للمنطقة \\
\hline 18.7 & 21 & الاهتمام بوسائل الطرق و المو اصلات \\
\hline 17.8 & 20 & الاهتمام بجودة التسهيلات و الخدمات السياحية \\
\hline 7.2 & 8 & الا هتمام بالخدمات الإرشادية للسائحين \\
\hline 5.4 & 6 & تو عية السكان المحليين بأهمية السياحة البيئية فى المنطقة \\
\hline 1.8 & 2 & الاهتمام بترويج أماكن السياحة البيئية \\
\hline 100 & 112 & الإجمالى \\
\hline
\end{tabular}

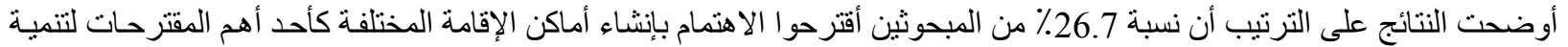

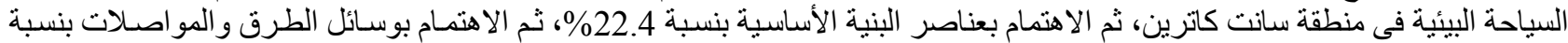

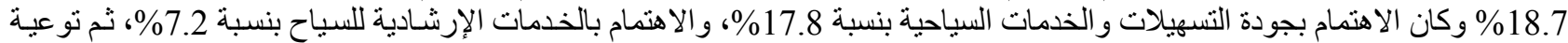
السكان المحليين بنسبة 5.4\%، وكان الاهتمام بترويج أماكن السياحة البيئية هى الاقتتر اح السابع من حيث الترتيب بنسبة 1.8\%

ثالثاً: تحليل نتائج المقابلات الثخصية:

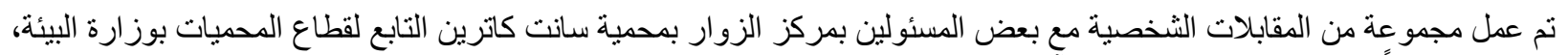

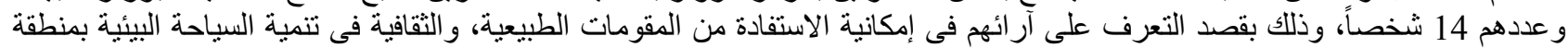
سانت كاترين لزيادة تدفق أعداد السائحين، وتحديد المعو قات التى التى تقابلها، وكانت نتيجة المقابلات الثخات الثخصية مايلى:

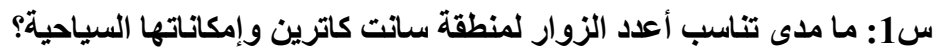

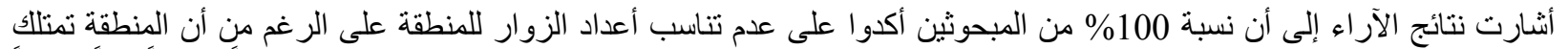

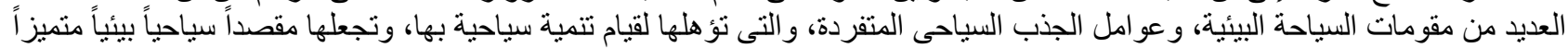
يستطيع المنافسة مع المقاصد السياحية المجاورة.

يتضح من ذلك ضعف الجهود التتشيطة والترويجية للشركات السياحية، و الهيئات المعنية فى زيادة الحركة السياحية إلى المنطقة.

س2: ماهى مقومات السياحة البيئية التى يمكن من خلالها تحقيق ميزة تنافسية لسانت كاترين؟

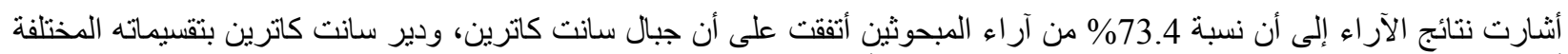

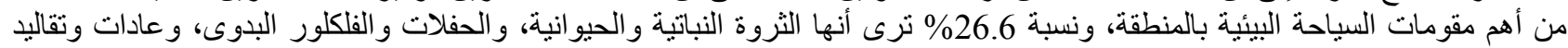
المجتمع المحلى بمنطقة سانت كاترين. يتضح من ذلك أن تعدد مقومات السياحية البيئية داخل منطقة سانت كاترين تساعد بدورها على تنشيط الحركة السياحية إليها، وجذب شر ائح جديدة من السائحين.

\section{س3: ماهى أهم الأنماط السياحية الموجودة فى منطقة سانت كاترين؟}

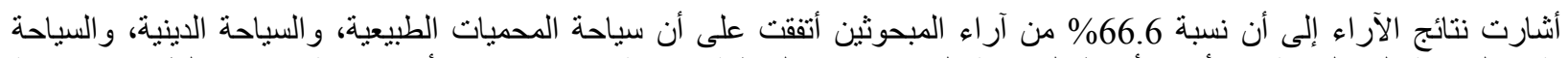

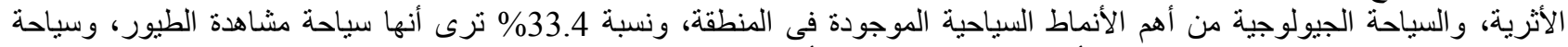
السفارى، والسياحة الرياضية وغير ها من الأنثطة السياحية البيئية الأخرى. يتضح من ذلك أن تعدد الأنماط السياحية داخل منطقة سانت كاترين تساعد على تقديم منتجات سياحية جديدة لإيجاد فرص عمل الإنل لأفراد

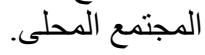


س4: ما مدى تقييكك لخدمات البنية الأساسية، وخدمات الضيافة بمنطقة سانت كاترين؟

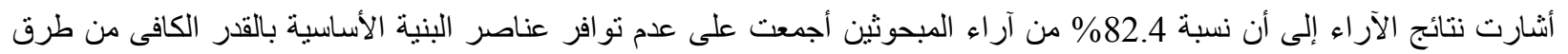

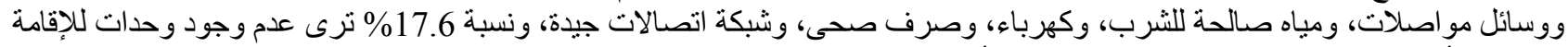

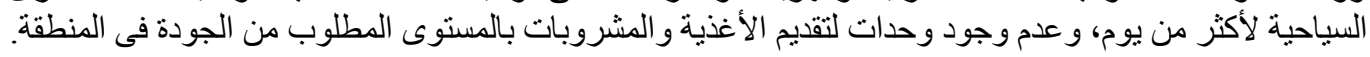

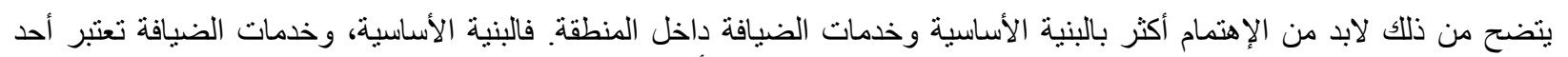
العو امل الرئيسية التى تؤثر على ضعف الإنى الحركة السياحية وقيام التنمية السياحية لأى منطقة.

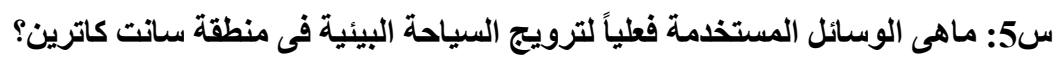

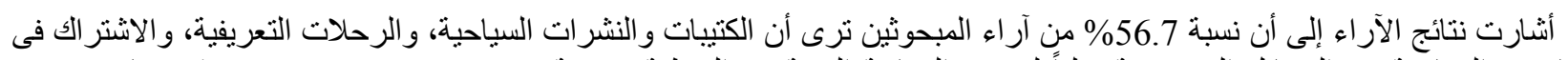

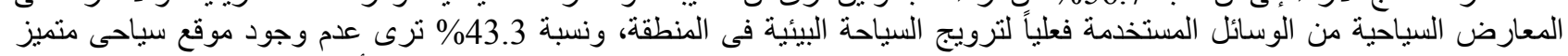
لدحافظة جنوب سيناء كمقصد سياحى، ولتعريف الز ائرين بها على شبكة الإنترنت مثلها مثل الددن السياحية الأخرى.

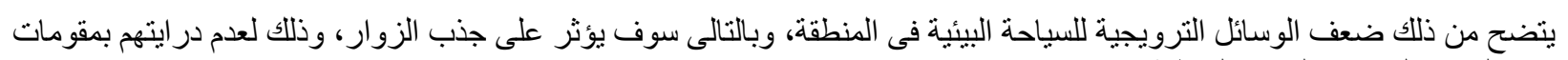
و وناصر الجذب السياحى البيئى بالمنطقة.

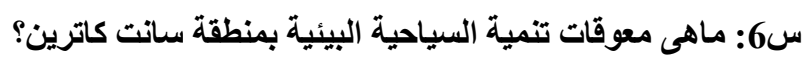

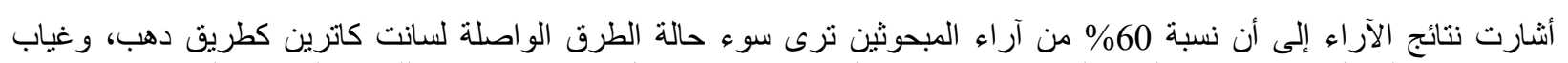

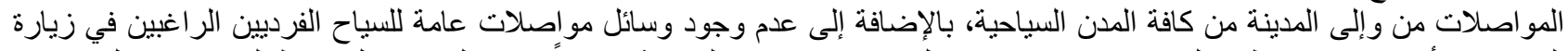

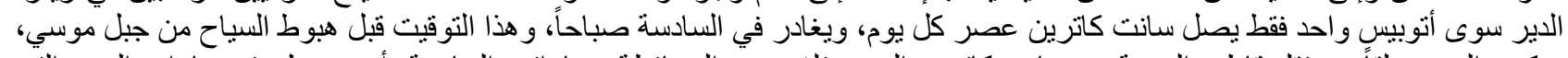

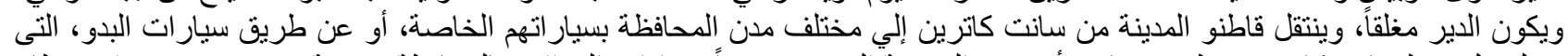

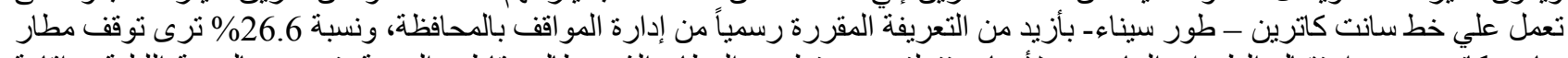

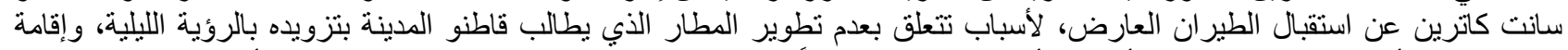

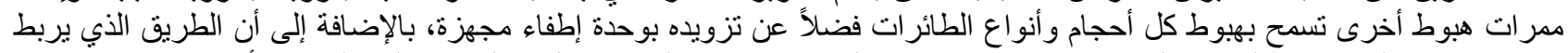

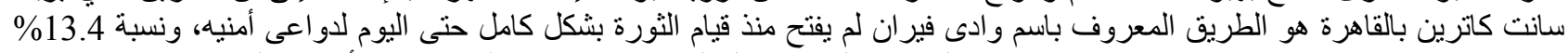

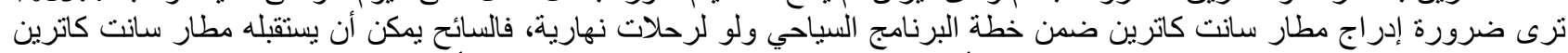

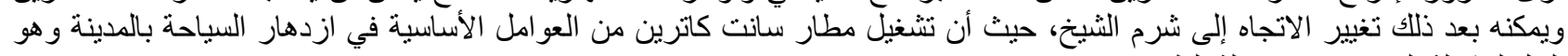

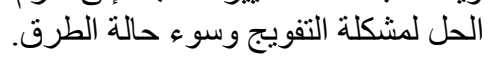

يتضح من ذلك أن كل هذه المعوقات تواجه التنمية السياحية البيئية بالمنطقة، وبالتالى سوف تؤثثر على زيادة أعداد الو افدين إليها.

\section{س7: ماهى معوقات جذب الاستثمارات السياحية إلى منطقة سانت كاترين؟}

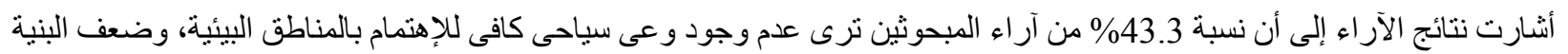

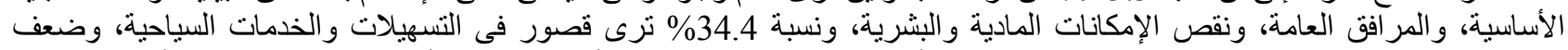

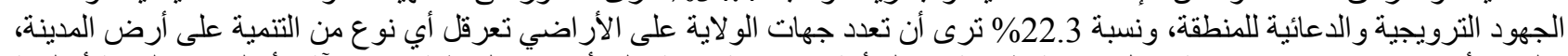

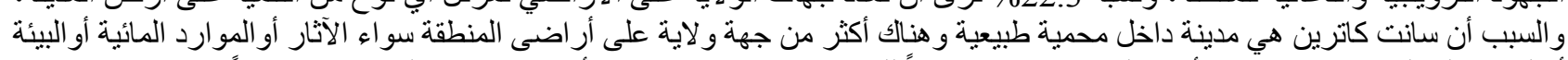

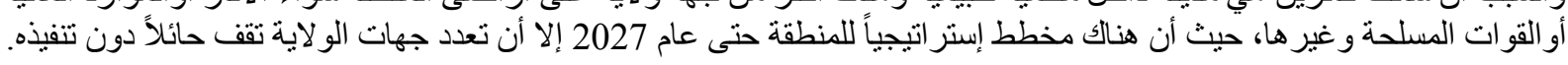

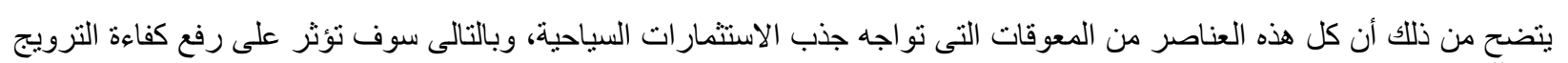
السياحى للمنطقة.

\section{س8: ماهى النتائج المترتبة على تنمية السياحة البيئية فى منطقة سانت كاترين؟}

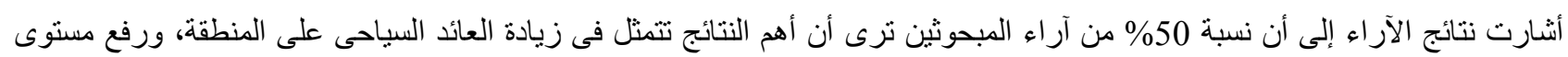

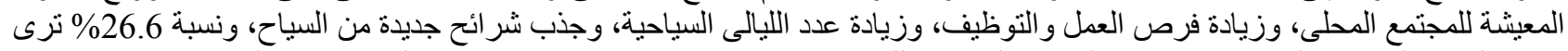

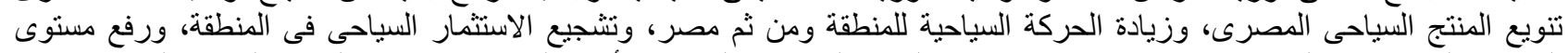

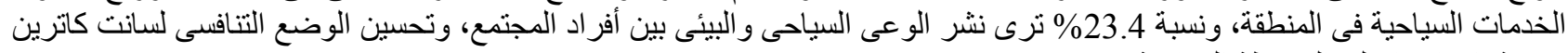

ومن ثم إدر اجها على الخريطة السياحية.

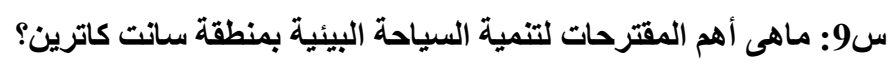

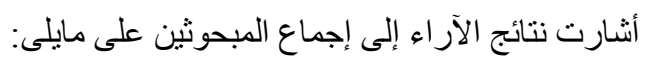

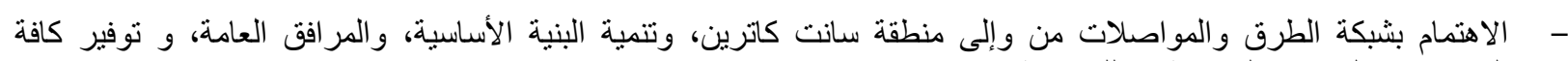

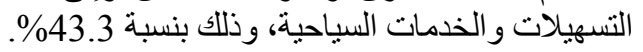

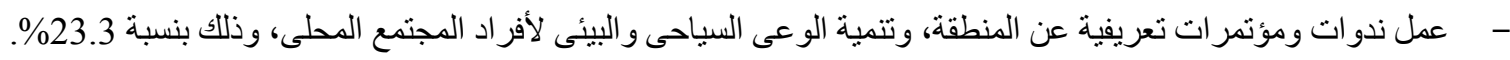

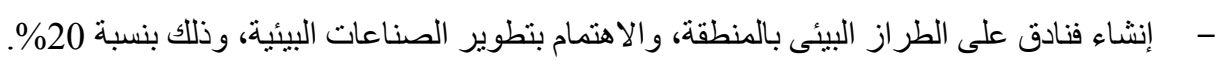

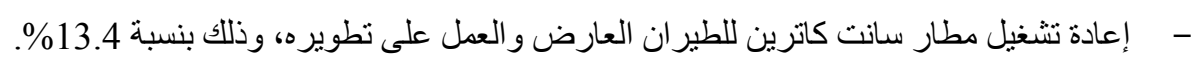




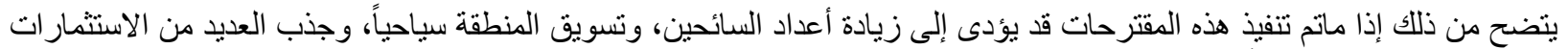

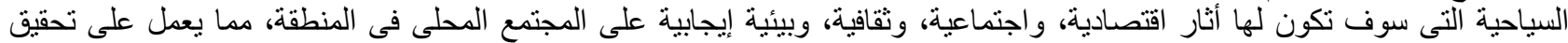
التنمية السياحية المنشودة.

س10: ماهى أهم إنجازات وزارة البيئة فى مجال تنمية وتطوير محمية ساتت كاترين؟ جاء السؤال العانشر من أسئلة المقابلات الثخصية للتعرف على أهم إنجازات وزارة البيئة فى مجال تتمية وتطوير محمية سانت كاترين،

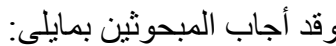

- البدء في تطوير محمية سانت كاترين، بعدما تم تخصيص 12.5 مليون جنيه لإنثاء خدمات للزوار من توفير مظلات وأماكن

لعرض منتجات السكان المحليين وصيانة وتطوير البنية الأساسية وغير ها.

- - البدء فى تتفيذ شبكة الطرق القومية من خلال التعاون مع الجهات المعنية بتطوير و إنشاء شبكة الطرق داخل المحمية، بتقديم

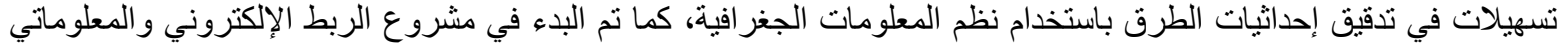
لشبكة المحميات

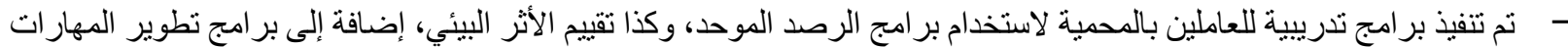

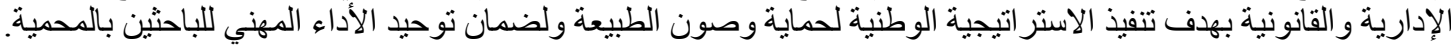

- ـ تم تنفيذ بر امج خاصة لتتمية وتطوير السكان المحليين للمحمية، خصوصـا في مجال تطوير وتسويق المنتجات اليدوية بما يضمن نوفير فرص عمل وتنمية دخل السكان المحليين.

- ـ شهدت المحمية مجموعة من الأنثطة والأحداث والر اليات و الزيارات السياحية المحلية والدولية، كما تم تتفيذ 5 رحلات سياحية طويلة بالمحمية.

- - تم إعداد خريطة جيولوجية حديثة لمحمية سانت كاترين بناء على المعلومات المتوفرة من صور الأقمار الصناعية مثل (أنواع الهاع الصخور، الكثبان الرملية، الوديان، الجبال)، وتحديث قواتية اعد البيانات الخاصة بالئة المحمية. - - مت إعداد أول حقيبة استثمارية داخل المحميات شملت مشرو عات استزراع النباتات الطبية بمحمية سانت كاترين. - - إعداد الدراسات الخاصة بإعلان الهيئة العامة لحماية الطبيعة، التى ستحدث طفرة كبيرة في مجال تتمية الدحميات وتزيل عو ائق الاستثمار داخل المحميات في مصر. باعل الخاص.

- ــ تم إعداد مقترح لتحديد مكان لمجمع الأديان بسانت كاترين بالتعاون مع وزارة السياحة، والذي يعد من مقومات التنمية السياحية بالمنطقة.

- - تجرى حاليا عمليات تجميل ونطوير للمواقع الأثرية والسياحية بدعم من وزارة السياحة كما أن محافظة جنوب سيناء بصدد تخصيص قطعة أرض لإقامة محطة تعمل بالطاقة الثمسية بمنطقة سانت كاترين.

لقد أنتهت الاراسة إلى النتائج التالية:

نتائج الاراسة الميدانية:

1- أغلب الزوار الو افدين إلى منطقة سانت كاترين من المصريين، والآسيو يين، والأوربيين.

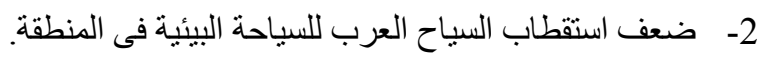

3- - الغالبية العظمى من زوار المنطقة متزوجون.

4- الفئة العمرية الأكثر زيارة للمنطقة هى شريحة منوسطى الأعمار.

5- احتلت شريحة التعليم العالى النسبة الأكبر بين زوار المنطقة.

6- أغلب الزوار لم يسبق لهم زيارة منطقة سانت كاترين.

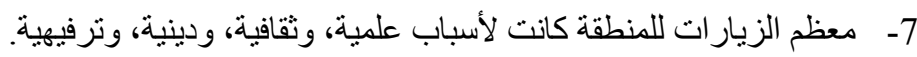

8- يؤكد الزوار على أن المنطقة مقصد متميز للسياحة البيئية.

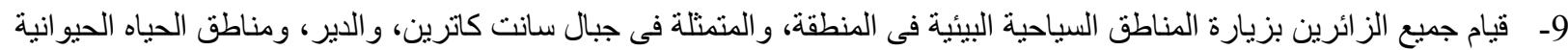

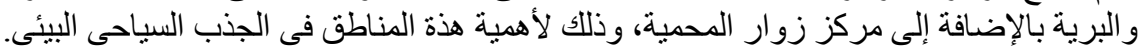

10ـ المعارف و الأصدقاء من أهم الوسائل التى أسنطاع من خلالها الزوار التعرف على المنطقة وزيارتها لممارسة الأنثطة السياحية 


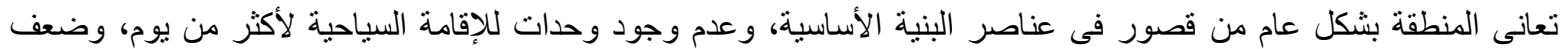

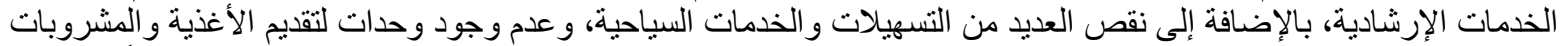

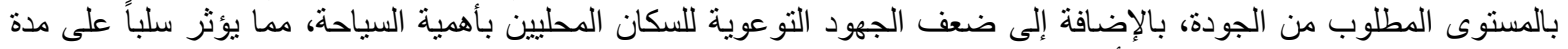
الزيارة، وحجم الطلب عليها، وزيادة أعداد السياح للمنطقة.

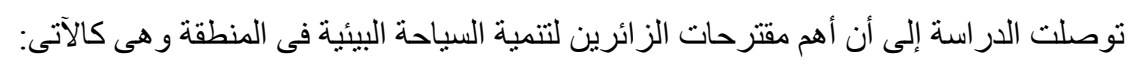

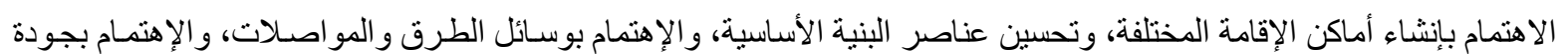

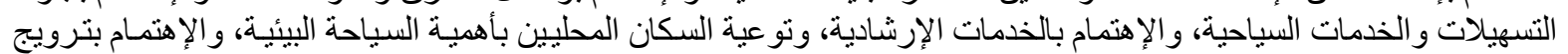
أماكن السياحة البيئية فى المنطقة.

لقد اتضخَ لنا من خلالِ هذه الدر اسة أن سانت كاترين تمتلك كافة مقومات السياحة البيئية هذا من جانب، ومن جانبٍ آخر فهناك عدد من التوصيات و المقترحات لتنمية السياحة البيئية في المنطقة كما يلي:

علي مستوى القطاعات الحكومية:

1- تحديد الأماكن السياحية، و العمل على تثيييد ودعم البني الأساسية، و الخدمات المساندة، بما يتفق مع كافة الاعتبار ات البيئية. 2- وضع الخطط و البرامج الكفيلة بإنشاء وتتفيذ مشاريع السياحة البيئية بالمنطقة، بحيث تتو افق مع المحافظة على البيئة، والآثار و التراث الحضاري و الثقافي. 3- العمل على جذب وتثجيع الاستثمارات في مجال السياحة البيئية، من خلال تقديم الحوافز والتسهيلات للمستثرين المصريين و الأجانب.

4- حصر و إحصاء وتوثيق الموارد و المقومات السياحية، في إطار قاعدة بيانات معلوماتية وترويجها محلباً وخارجياً.

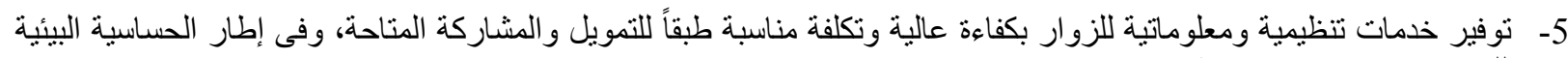
للمو اقع وقدر اتها الاستيعابية. 6- إعداد مستوى جيد من المرشدين السياحيين و الباحثين البيئين القادرين على تقديم معلومات تفصيلية وصحيحة للسائحين.

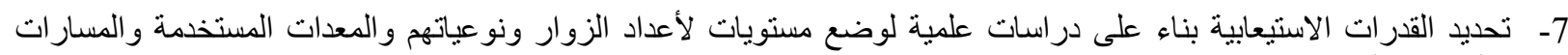
و الخدمات اللازمة. 8- دعم الحرف اليدوية السياحية والتذكارية بما يخدم البيئة السياحية وينثط المو ارد المالية لسكان المنطقة، وللدولة.

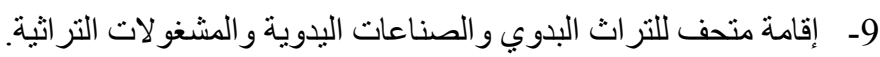

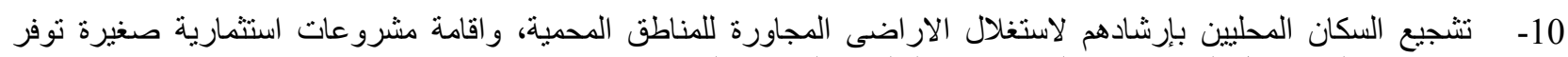

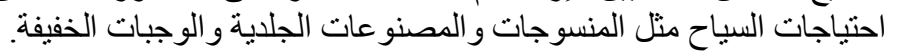

11- إنشاء بنك متخصص لاعم الاستثمار في المشرو عات السياحية، خاصة في مجال السياحة البيئية.

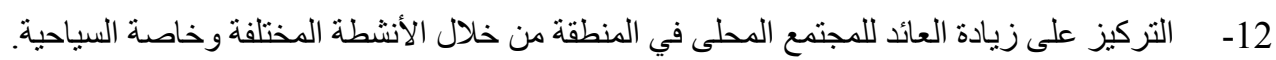
تنمية الثر اكة بين الأطراف المعنية بالسياحة البيئية لتنفيذ خدمات على نطاق واسع وتمويل البرامج للارتقاء بالبيئة بما بحقق الفائدة المشتركة وانجاز الأهداف المرجوة للجميع.

\section{علي مستوي القطاع الخاص والجهات القائمة علي صناعة السياحة:}

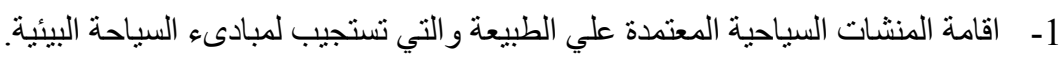

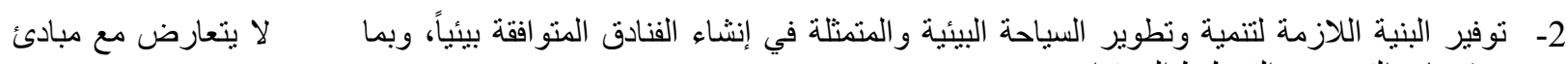
ومقومات التصميم و التخطيط المستدام.

3- وضع الخطط اللازمة للحد من تلوث البيئة في المنشآت السياحية، مع در اسة إمكانات تحو يلها مرحلياً الي فنادق بيئية.

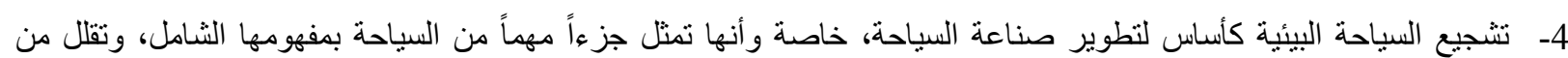
النسرب السياحي المتمثل في الإنفاق السياحي المبانثر للخارج.

$$
\text { 5- التركيز علي تنويع المستويات في مشرو عات السياحة البيئية لتناسب جميع فئئات وشر ائح المواطنين. }
$$

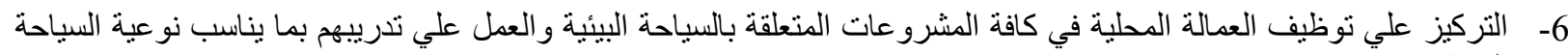
البيئية. 7- وضع دليل سياحي شامل وخر ائط شاملة مناخية وبيولوجية وحيو انية ونباتية، وخر ائط لأماكن الآثار والمتاحف يسير على هديها ويسترشد بها السيائح الأجنبى والمصرى. 
8- الاهتمام بتوفير وتطوير مقومات السياحة الر اقية التي تتمثل في البنية الأساسية من طرق، ومياه، وكهرباء، وصرف وف صحى في

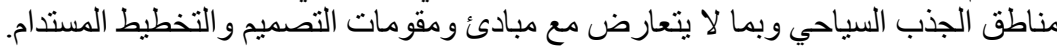

دمج سكان المجتمع المحلى وتو عيتهم وتثقيفهم بيئياً وسياحياً، وتوفير مشرو عات اقتصادية للاخل من خلال تطوير صناعات سياحية

وتحسين ظروف معيشتنه.

علي مستوى زيادة الوعي:

1- التو عية البيئية لكافة شر ائح المجتمع من خلال وسائل الإعلام بأنو اعها المختلفة.

2- العمل علي نشر الثقافة البيئية فضلاً عن الثقافة السياحية وزيادة الوعي السياحي.

3- ضرورة إنشاء وحدة الإعلام السياحي المتخصصة لوضع البرامج الإعلامية لأجهزة الإعلام المحلية والإقليمية والعالمية.

4- تفعيل دور المنظمات غير الحكومية في نشر التوعية والتثقيف الصحي والبيئي وتشجيع المواطنين على المشاركة الفعالة في حماية البيئة وورقاية أنفسهم.

علي مستوي التعليم:

1- الاهنمام بالتعليم السياحي وتأهيل الكوادر المحلية من خلال إنثاء الكليات والمعاهد الخاصة بالسياحة البيئية في مناطق الجذب السياحي.

2- ضرورة ادخال مفهوم السياحة البيئية في مادة التربية الوطنية كمادة أساسية في عدد من المر احل الدراسية لاظهار آثار ها الثقافية، والاجتماعية، و الاقتصادية.

3- الاهتمام بالتربية البيئية ودمج الأبعاد البيئية والصحية في المواد التعليمية في مر احل التعليم المختلفة وتوعية وتثقيف المواطنين للحد من التدهور وحماية البيئة من التلوث.

4- إيجاد آلية مثتركة لتفعيل مدى إمكانية الاستفادة من محميات الحياة الفطرية بالرحلات البرية للتعريف بالسياحة البيئية.

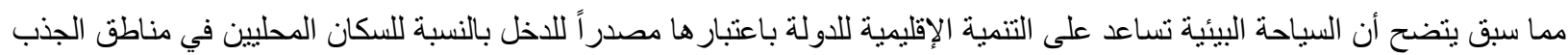

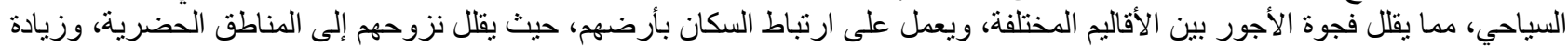

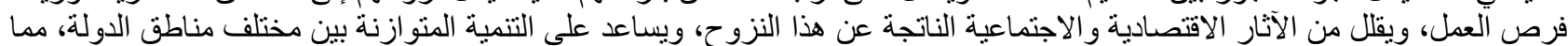

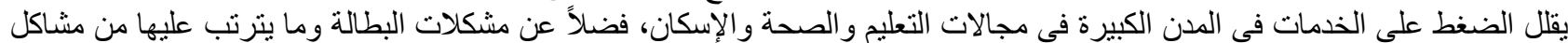

اقتصادية و اجتماعية و أمنية.

المراجع

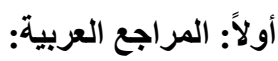

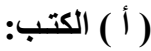

1- الخضيرى، محسن أحمد (2004): صناعة المزايا التنافسية، مجموعة النيل العربية، القاهرة، ص39.

2- الصر ايرة، محمد (2012): السياحة البيئية بين النظرية والتطبيق، مؤسسة الوراق للنشر والتوزيع، عمان، ص83-84.

3- الصيرفي، محمد (2007): السياحة البيئية، منشور ات دار الفكر الجامعي، الاسكندرية ، 2007 ، ص 196

4- العانى، رعد مجيد (2008): الإستثمار و التسويق السياحى، دار كنوز المعرفية العلمية للنشر والتوزيع، عمان، ص71.

5- القصاص، محمد (2007): الإنسان و البيئة و التنمية، دار المعارف، ص19-20.

6- اللحام، نسرين (2008): التخطيط السياحى للمناطق التراثية باستخدام تقنية تقييم الآثار البيئية، دار النيل للنشر والتوزيع، القاهرة،

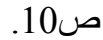

7- - النجار، فريد (2010): السياحة البيئية كمدخل لتحقيق التتمية المستدامة، مكتبة الدار العربية للكتاب، القاهرة، ص171.

8- -

9- -

10- شوفى، قطب (2009): أهمية قطاع النقل والسياحة ودور هما فى استثمار الموارد البشرية والاقتصادية، مجموعة النيل العربية،

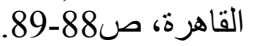

11 - عبد الرحمن، عادل محمد (2014): المحميات الطبيعية فى مصر ، دار ومكتبة الإسراء ، ص121.

12- عبد السميع، أحمد (2008): علم الإقتصاد السياحى، دار الوفاء، الإسكندرية، ص257. 
13- عبد اللطيف، رشاد أحمد (2007): البيئة والانسان - منظور اجتماعى، دار الوفاء، ص13.

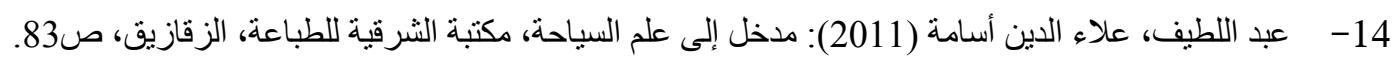

15- عبد الله، سليمان (2013): مبادئ صناعة الضيافة، مكتبة الأمل للطباعة، القاهرة، ص414-42.

16- عبد ربه، محمد عبد الكريم (2004): اقتصاديات الموارد والبيئة، دار المعرفة الجامعية، ص88.

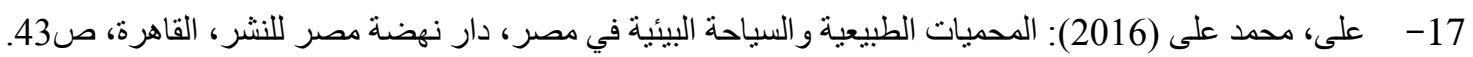

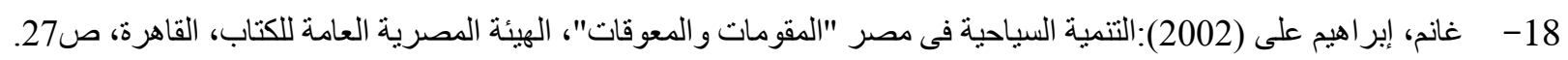

19- فؤاد، نشوى (2008): تتمية المبيعات السياحية، دار الوفاء لدنيا الطباعة و النشر، الإسكندرية، ص12.

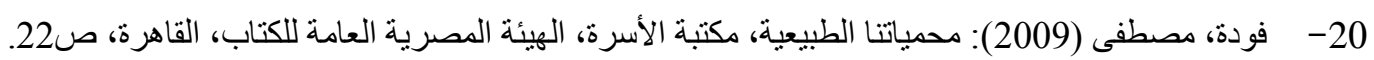

21- نوفل، نبيل (2002): مناهج البحث فى التربية، دار المعارف، القاهرة، ص26.

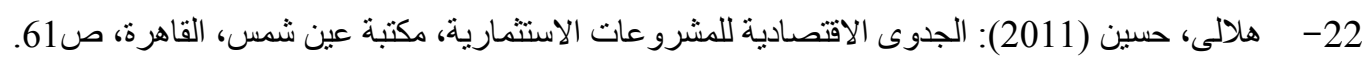

23- و هدان، شريف حسنى (2013): التخطيط لسياحى، مطبعة الأمل للطباعة، القاهرة، ص87.

(ب) الرسائل العلمية والاراسات:

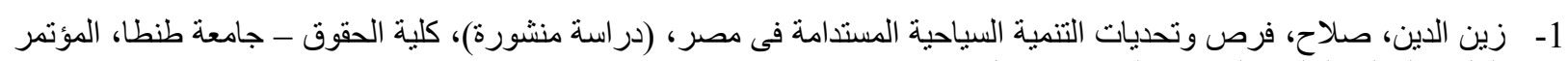

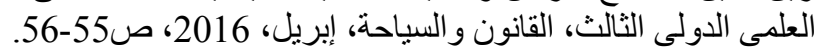

2- عبد الجليل، هويدى (2014): العلاقة التفاعلية بين السياحة البيئية والتتمية المستدامة، (دراسة منشورة)، جامعة الوادي، مجلة

الدراسات و البحوث الاجتماعية، العدد 9 ، ديسمبر 2014 ص223.

3- عبد الخالق، السيد ثابت (2005): المحميات الطييعية فى شبه جزيرة سيناء، رسالة ماجستير (غير منشورة)، كلية الآداب، جامعة

بنها، ص141. (141.

4- عبد المعبود، عوض صالا، (2007): المحميات الطبيعية فى مصر در اسة لمتغيرات البيئة الجغر افية، رسالة دكتور اه (غير منشورة)، كلية

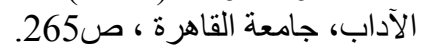

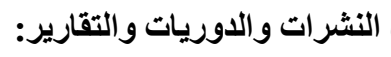

1- - البوابة الإلكترونية لهحافظة جنوب سيناء، 2017.

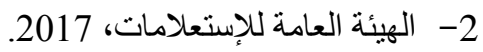

3- محافظة جنوب سيناء، مركز المعلومات ودعم اتخاذ القرار،إدارة الإحصاء، 2015.

4- وزارة الدولة لشئون البيئة، جهاز شئون البيئة، المنتدى البيئى للسياحة و البيئة، الإدارة المركزية لحماية الطبيعة، يونيو، 2013.

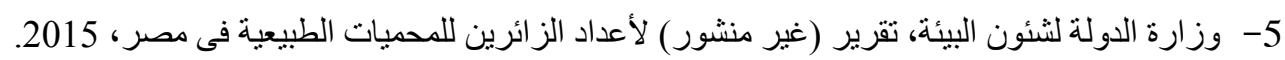

6- وزارة الدولة لشئون البيئة، جهاز شئون البيئة، الإدارة المركزية لحماية الطبيعة، 2015.

ثانياً: المراجع الأجنبية:

1- Alejandro, D. (2008): Tourism Development: Economics, management and Strategy. Nova Science Publishers, Inc, U.S.A.

2- Buckley, R, (2003): Nature - based tourism Environment and land management, CABI publishing, first Edition, UK.

3- Campbell, B, (2011): Ecotourism, Examples from the field, springer publications, first Edition, U.S.A.

4- Butcher, Jim, (2007): Ecotourism, NGOS and development acritical analysis, routledg, publication, first Edtion, U.S.A.

5- Charles, R. G. (2006): Tourism, Principles, Practices, Philosophies. Published By John Wiley \& Sons, Inc, U.S.A. 
6- Durham, W, (2008): Ecotourism and conservation in the Americas, CABI publication first Edition, U.S.A.

7- Fennell, David, (2005): Ecotourism an introduction, routladg, publication first Edition, UK.

8- Paul, F. (2002): Sustainable Tourism in Protected Areas: Guidelines for Planning and Management.International Union for Conservation of Nature and Natural Resources, UK.

9- World tourism organization (2010): tourism for nature and development, good practice guid, convention on biological diversity, Montreal.

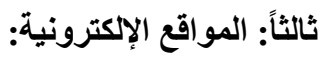

1- http://almogaz.com/news/politics/2150113 (accessed on 23/12/2015).

2- http://www.southsinai.gov.eg/tourism/protected/santchathren/default.aspx (accessed on 21/2/2017).

3- http://www.masrawy.com/Howa_w_Hya/Health/details//10635 (accessed on 19/4/2017).

4- http://www.albawabhnews.com/762049 (accessed on 31/8/2014).

5- http://www.elfagr.org/2261068 (accessed on 3/9/2016).

\title{
Development of eco-tourism in Egypt and a strategy of inclusion it on the tourist map \\ (Applied to St. Catherine protectorate)
}

\begin{abstract}
Alaa eldin Osama Abd ellatif
Abstract

This research aims to identify all the natural environmental potentials of St-Catherine area and to highlight its important role in the development of the environmental tourism in Egypt, and then to plan a strategy for it's developing and including it on the Egypt's tourist map.

The findings showed that St.Catherine protectorate has several Ingredients of ecotourism which represent great importance and value especially from the tourist point of view.

Among the research recommendations are: Setting plans and programmes to establish and implement the tourism projects in the area of St.Catherine that is compatible with conservation of the environment, monuments, civilization and cultural heritage.
\end{abstract}

Key words: eco-tourism, the strategy, the tourist map, St. Catherine protectorate. 